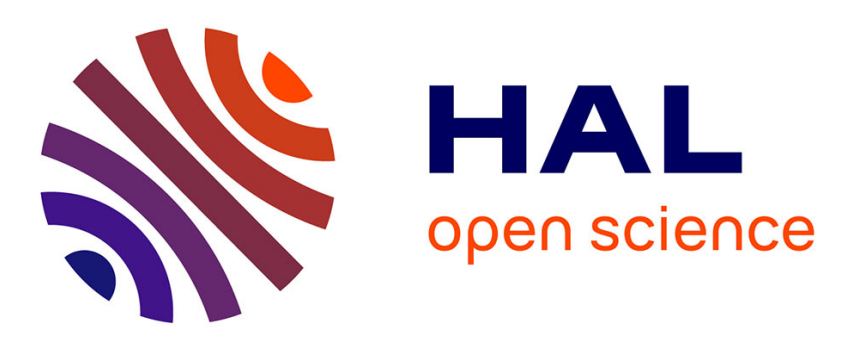

\title{
Carbonation by fluid-rock interactions at high-pressure conditions: Implications for carbon cycling in subduction zones
}

Francesca Piccoli, Alberto Vitale Brovarone, Olivier Beyssac, Isabelle Martinez, Jay J. Ague, Carine Chaduteau

\section{To cite this version:}

Francesca Piccoli, Alberto Vitale Brovarone, Olivier Beyssac, Isabelle Martinez, Jay J. Ague, et al.. Carbonation by fluid-rock interactions at high-pressure conditions: Implications for carbon cycling in subduction zones. Earth and Planetary Science Letters, 2016, 445, pp.146-159. 10.1016/j.epsl.2016.03.045 . hal-01311634

\section{HAL Id: hal-01311634 https: / hal.sorbonne-universite.fr/hal-01311634}

Submitted on 4 May 2016

HAL is a multi-disciplinary open access archive for the deposit and dissemination of scientific research documents, whether they are published or not. The documents may come from teaching and research institutions in France or abroad, or from public or private research centers.
L'archive ouverte pluridisciplinaire HAL, est destinée au dépôt et à la diffusion de documents scientifiques de niveau recherche, publiés ou non, émanant des établissements d'enseignement et de recherche français ou étrangers, des laboratoires publics ou privés. 
Carbonation by fluid-rock interactions at High-Pressure conditions: implications for carbon cycling in subduction zones

3

4 Francesca Piccoli $^{\mathrm{a},}$, Alberto Vitale Brovarone ${ }^{\mathrm{a}}$, Olivier Beyssac ${ }^{\mathrm{a}}$, Isabelle Martinez ${ }^{\mathrm{b}}$, Jay J. 5 Ague $^{\mathrm{c}, \mathrm{d}}$, Carine Chaduteau ${ }^{\mathrm{b}}$

6

${ }^{a}$ Insitut de Minéralogie, Physique des Matériaux et Cosmochimie (IMPMC), UPMC-CNRS Campus Jussieu, case courrier 115, 4 Place Jussieu, 75005, Paris, France. Tel. 0033 (0)1 44272560

9 ' Institut de Physique du Globe de Paris, Sorbonne Paris Cité, Université Paris Diderot, UMR 7154 CNRS, 1 rue 10 Jussieu, F-75005 Paris, France

$11{ }^{c}$ Department of Geology and Geophysics, Yale University, P.O. Box 208109, New Haven, CT 06520-8109, USA

${ }^{\mathrm{d}}$ Peabody Museum of Natural History, Yale University, 170 Whitney Avenue, P.O. Box 208118, New Haven, CT, 06520-8118, USA

14

15

*francesca.piccoli@impmc.upmc.fr

16

17

18

19

20

21

22

23

24

25

26

27

28

29

30

31

32 
Carbonate-bearing lithologies are the main carbon carrier into subduction zones. Their evolution during metamorphism largely controls the fate of carbon, regulating its fluxes between shallow and deep reservoirs. Recent estimates predict that almost all subducted carbon is transferred into the crust and lithospheric mantle during subduction metamorphism via decarbonation and dissolution reactions at high-pressure conditions. Here we report the occurrence of eclogite-facies marbles associated with metasomatic systems in Alpine Corsica (France). The occurrence of these marbles along major fluid-conduits as well as textural, geochemical and isotopic data indicating fluid-mineral reactions are compelling evidence for the precipitation of these carbonate-rich assemblages from carbonic fluids during metamorphism. The discovery of metasomatic marbles brings new insights into the fate of carbonic fluids formed in subducting slabs. We infer that rock carbonation can occur at highpressure conditions by either vein-injection or chemical replacement mechanisms. This indicates that carbonic fluids produced by decarbonation reactions and carbonate dissolution may not be directly transferred to the mantle wedge, but can interact with slab and mantleforming rocks. Rock-carbonation by fluid-rock interactions may have an important impact on the residence time of carbon and oxygen in subduction zones and lithospheric mantle reservoirs as well as carbonate isotopic signatures in subduction zones. Furthermore, carbonation may modulate the emission of $\mathrm{CO}_{2}$ at volcanic arcs over geological time scales.

\section{Introduction}


Subduction exerts a key role in the long-term carbon cycle by regulating the fluxes of carbon between the Earth's surface and the deep Earth. The redistribution of carbon between the exogenic and endogenic reservoirs largely depends on the evolution of carbonate-bearing lithologies in subduction zones. Carbonates are present in sedimentary, mafic and ultramafic lithologies, and constitute the dominant reservoir of carbon in the subducting lithosphere (Alt and Teagle, 1999; Kelemen \& Manning, 2015). There is growing evidence that carbonates can be extremely reactive during subduction metamorphism via devolatilization reactions (Cook-Kollars et al., 2014; Kerrick \& Connolly, 2001), as well as carbonate dissolution via fluid-rock interactions at high-pressure conditions (Frezzotti et al., 2011; Ague and Nicolescu, 2014; Kelemen and Manning, 2015), carbonate reduction reactions (Galvez et al., 2013a; Malvoisin et al., 2012), or melting of the subducting crust (Poli, 2015). Nonetheless, key questions remain regarding the mechanisms of carbonic fluid transfer from the slab to the lithospheric mantle in the sub-arc region, their role in mantle wedge metasomatism, and their contribution to the $\mathrm{CO}_{2}$ degassing at volcanic arcs.

To address these questions, a growing number of studies have been carried out using both experimental petrology (Molina and Poli 2000; Poli et al., 2009) and thermodynamic modeling (Kerrick and Connolly 2001; Gorman et al., 2006). All these studies agree that, considering a "closed system" (no external fluid supply), significant carbon transfer to the mantle wedge is feasible only at shallow depth in the forearc region. This transfer is made possible via devolatilization reactions that, based on experimental and thermodynamic results, are much more limited at deeper, subarc conditions (Connolly, 2005; Poli et al., 2009). Nevertheless, the role of fluid-rock interactions appears to be critical for the stability of carbonates. Recently, field based studies (Ague and Nicolescu, 2014; Frezzotti et al., 2011) as well as theoretical and experimental works (Facq et al., 2014; Sverjensky et al., 2014) have pointed out that massive carbonate dissolution in fluids may occur at high-pressure-low 
temperature conditions and can generate large amounts of carbonic fluids (see Kelemen and Manning, 2015 for review). Accounting for carbonate dissolution at high-pressure conditions in comprehensive budgets overturns older paradigms on carbonate stability with respect to carbon mobility in subduction zones. The most recent budgets actually predict that carbonate dissolution allows almost all subducted carbon to be transferred to the mantle wedge (Kelemen \& Manning, 2015). Owing to the very recent discovery of these processes, much remains to be learned about the fate of these carbonic fluids and their interaction with slaband mantle-forming rocks.

Here, we report the occurrence of eclogite-facies marbles formed by fluid-rock interaction processes (metasomatism) occurring along intensely metasomatized lithological interfaces (Alpine Corsica, France). We present and discuss the occurrence, textures, mineralogy and geochemistry of these metasomatic marbles. We then propose a mechanism of carbonates formation by precipitation and mineral carbonation by carbonic fluid-rock interactions at high-pressure conditions. Finally, the implications and contribution of rock carbonation to the deep carbon fluxes and cycling are discussed.

\section{Geological setting}

Alpine Corsica (France) is a branch of the Alpine orogenic system (Jolivet et al., 1991; Molli and Malavieille, 2011) (Fig.1a). The belt mainly includes remnants of subducted Mesozoic slow-spreading oceanic and passive margin lithosphere, which formed part of the Tethys Ocean basin. This rock package is classically referred to as the Schistes Lustrés Complex (Fig. 1b; Jolivet et al., 1990; Fournier et al., 1991; Malavieille et al., 1998; Vitale Brovarone et al., 2013). The exceptional preservation of prograde-to-peak mineral assemblages, including widespread lawsonite, makes the Schistes Lustrés of Alpine Corsica an excellent 
111 site for field investigations related to subduction. These units underwent various metamorphic

112 overprints during the Alpine subduction ranging from subgreenschist-facies conditions of 113 about $300^{\circ} \mathrm{C}$ and $0.5 \mathrm{GPa}$ to lawsonite blueschist and lawsonite eclogite-facies conditions 114 which reached $500-550{ }^{\circ} \mathrm{C}$ and $\sim 2.3 \mathrm{GPa}$ (e.g. Fournier et al., 1991; see Vitale Brovarone et 115 al., 2013 for review). most typical carbonate-bearing lithologies are metamorphosed oceanic sediments (referred to 118 as calcschists hereafter), ophicarbonate, and carbonated metabasalts (Miller et al., 2001; 119 Ravna et al., 2010; Vitale Brovarone et al., 2011b). In each lithology, primary carbonates and various generations of carbonate veins are observed (Miller et al., 2001; Ravna et al., 2010;

121 Vitale Brovarone et al., 2011b). These veins have been shown to be in most cases in isotopic 122 equilibrium with the host rocks with little effect of external fluid infiltrations and 123 metasomatism (Cartwright and Buick, 2000). On the other hand, evidence for high-pressure124 low temperature fluid-rock interactions and metasomatism in the Schistes Lustrés of Alpine 125 Corsica is widespread, most typically localized at lithological interfaces. In this work, we 126 focus on processes occurring where serpentinites are in contact with metasedimentary rocks. Here, past results on high-pressure metasomatism in Alpine Corsica are briefly summarized. In the blueschist-facies zone, reactions between serpentinites and overlying metasediments led to carbonate reduction and precipitation of wollastonite and abiotic 130 graphite at blueschist-facies conditions (Malvoisin et al., 2012; Galvez et al., 2013a). Except 131 for the influx of external, serpentinite-derived fluids, the reacted metasediments revealed 132 largely conservative carbon budget (Galvez et al., 2013a). In similar lithological settings, 133 massive precipitation of lawsonite from fluid-rock interactions at the expense of 134 metasedimentary rocks in contact with serpentinites testifies to the reincorporation of large 135 amounts of water in the rock at prograde blueschist-to-eclogite-facies metamorphic conditions 
136 (Martin et al., 2011; Vitale Brovarone et al., 2014; Vitale Brovarone and Beyssac, 2014;).

137 This process is characterized by a dramatic whole-rock chemical modification leading to

138 mafic/ultramafic, Ca-rich metasomatic products.

139 The carbonate-rich rocks studied herein are intimately related to the latter Ca-rich 140 metasomatic rocks and were collected in the lawsonite eclogite-facies San Petrone unit. This

141 unit is characterized by a basal body of serpentinite variably overlain by Jurassic pillow

142 metabasalts, Mesozoic metasediments (e.g. calcschists, marbles, Mn-metacherts) or slivers of

143 Hercynian continental basement rocks mainly consisting of pre-Alpine, carbonate-free, high-

144 temperature metasediments and granitic rocks overprinted at high-pressure-low temperature 145 conditions during the Alpine subduction (Vitale Brovarone et al., 2011b; Fig. 1c).

146 Ophicarbonate rocks are locally found at the top of the serpentinite body. The San Petrone

147 unit has been considered as a remnant of a Mesozoic hyper-extended passive margin (Vitale

148 Brovarone et al., 2011b; Beltrando et al., 2014). Peak metamorphic conditions in this unit are

149 estimated at ca. $490-530{ }^{\circ} \mathrm{C}$ and $\sim 2.3 \mathrm{GPa}$ by means of pseudosection modeling and

150 thermometry based on Raman spectroscopy of carbonaceous material (Ravna et al., 2010;

151 Vitale Brovarone et al., 2011a, 2013). The peak metamorphic age of 34 Ma has been

152 determined by several techniques including U-Pb zircon and $\mathrm{Lu}-\mathrm{Hf}$ garnet and lawsonite 153 geochronology (Martin et al., 2011; Vitale Brovarone and Herwartz, 2013).

\section{Structural occurrence of metasomatic marbles}

156 The carbonate-rich rocks which are the subject of this paper occur along a regional

157 lithological boundary separating serpentinites from either slivers of Hercynian basement 158 rocks (dominantly pre-Alpine high temperature metasedimentary rocks) or Mesozoic 159 metasedimentary rocks (Figs. 1c and 2). The first few meters of rock above the serpentinites 
160 exhibit intense Alpine metasomatism that has already been described in previous studies

161 (Martin et al., 2011; Vitale Brovarone et al., 2011b, 2014). These metasomatic rinds can be

162 followed for several kilometers along the top of the serpentinite body and are characterized by

163 lawsonite-rich assemblages, but diopside-rich rocks are also common. These rocks are

164 referred to as Stage\#1 diopside-lawsonite rocks (Fig.2). The carbonated rocks which are the

165 subject of this study are referred to as Stage\#2 metasomatic marbles (or simply metasomatic

166 marbles), these form discontinuous patches or lenses of variable thickness and lateral

167 extension (from a few tens of $\mathrm{cm}$ to several m, Fig. 2), and are preferentially associated with

168 diopside-rich rather than the lawsonite-rich metasomatic rocks. The petrological differences

169 between Stage\#2 metasomatic marbles and Mesozoic metasediments are discussed in Section

$170 \quad 5$.

171 The metasomatic marbles show a range of structural relationships with the surrounding

172 diopside-lawsonite rocks, and the carbonate/host rock ratios are extremely variable. Figure 2

173 summarizes the field relationships between the different rock types, i.e. serpentinites, Stage\#1

174 diopside-lawsonite rocks, Stage\#2 metasomatic marbles, and the inferred protolith rocks

175 (continental basement rocks or Mesozoic metasediments). The transition from diopside-

176 lawsonite rocks to Stage\#2 metasomatic marbles is marked by a gradual increase of

177 carbonate/host rock ratio, passing from diopside-lawsonite rocks to isolated carbonate-rich

178 veins in Stage\#1 host rocks, to Stage\#2 metasomatic marbles with remnants of Stage\#1 rocks.

179 Isolated veins have crack-seal texture and are mainly composed of rod-shaped Ca-carbonate \pm

180 omphacite (Figs. 3a, b, d). Carbonate rods are perpendicular to the vein walls (Fig. 3b).

181 Omphacite grows from the vein wall toward the center (Fig. 3d). Some veins exhibit

182 interaction with the host Stage\#1 rocks characterized by omphacite replacement of the

183 precursor diopside (Al-Na gain; Ca-Mg loss) and local carbonate precipitation (Fig. 3d). The

184 abundance of omphacite decreases from the vein wall to the host rock. Diopside far from the 
vein does not display any chemical zoning involving Na-Al enrichment. The isolated veins

186 are connected to dm-thick layers (ca. $20 \mathrm{~cm}$ ) showing similar crack-seal textures (Figs. 2 and

187 3a). These layers are meter-scale and are parallel to the wallrock foliation (Fig. 2). Outcrop188 scale hydraulic breccias consisting of $\mathrm{cm}$ - to $\mathrm{m}$-scale angular clasts of Stage\#1 diopside189 lawsonite rocks embedded within a carbonate vein network provide strong evidence for 190 diffuse hydrofracturing and carbonate precipitation (Figs. 2, 3e and f).

191 In some outcrops, serpentinites are overlain by a sequence of metasomatic marbles ranging in

192 thickness from less than one $\mathrm{m}$ to $\sim 10 \mathrm{~m}$ (Figs. 2, 3g and 4a). These metasomatic marbles are

193 hosted within the diopside-lawsonite rock and contain remnants of the host rock-ranging 194 from a few microns to several centimeters-floating in a carbonate-dominated matrix. 195 Remnants of diopside-lawsonite rocks in the metasomatic marbles differ from the angular 196 clasts found in the hydraulic breccias. First, they have embayed margins and microtextures

197 (see Section 5) suggest digestion of the silicate portions into the carbonate matrix. Second, the 198 host rock remnants preserve their original orientation (Fig. 4a), whereas the clasts in the 199 hydraulic breccias have random rotation (Figs. 2). Last, the diopside remnants are commonly 200 rimmed by omphacite, the latter being in textural equilibrium with the carbonate as observed 201 in the isolated carbonate veins.

\section{Methods}

\subsection{Scanning electron microscopy and electron microprobe}

205 Petrographic thin sections were carbon coated for scanning electron microscopy (SEM). 206 Observations were performed at a working distance of $7.5 \mathrm{~mm}$ using a Zeiss Ultra 55 field 207 emission gun SEM operated at $15 \mathrm{kV}$ with a $120 \mu \mathrm{m}$ aperture. Backscattered electron (BSE) 208 mode was used to investigate chemical heterogeneities using an Angle Selective 
Backscattered Detector (AsB) or an Energy Selective Backscattered Detector (EsB). Energy

210 dispersive X-ray spectrometry (EDXS) maps were acquired using an EDXS QUANTAX 211 system equipped with a silicon drift detector XFlash 4010 (Bruker). Data were processed with

212 the software Esprit (Bruker). Mineral analyses were performed on a Cameca electron 213 microprobe (either SX-100 or SX Five) (Camparis, Université Paris 6). Common analytical 214 conditions were adopted for spot analyses [15 kV, $10 \mathrm{nA}$, wavelength-dispersive spectroscopy 215 (WDS) mode], using $\mathrm{Fe}_{2} \mathrm{O}_{3}, \mathrm{MnTiO}_{3}$ (Mn, Ti), diopside (Mg, Si), orthoclase (Al, $\mathrm{K}$ ), 216 anorthite $(\mathrm{Ca})$ and albite $(\mathrm{Na})$ as standards. The automated Cameca ZAF procedure was used 217 for quantification (Tables S1, S2, S4 and S5).

\subsection{Whole rock major and trace element data}

219 Chips of low to highly carbonated rock were removed from hand-samples. Samples were crushed in an agate mortar (grain size $<80 \mu \mathrm{m}$ ) and sent for major and trace element, $\mathrm{CO}_{2}$ and organic carbon analyses at the Service d'Analyse des Roches et Minéraux (SARM, Centre de Recherches Pétrographiques et Géochimiques, Nancy, France) by alkali fusion of rock samples $\left(\mathrm{LiBO}_{2}\right)$, followed by concentration measurements using an ICP-OES Icap 6500

224 (Thermoscientific) for major elements, and an ICP-MS X7 (Thermoscientific) for minor 225 elements (protocol by Carignan et al., 2001). The modal proportions of silicates vs. carbonate were estimated first with optical microscopy and then checked using whole rock and mineral composition. In two cases, samples 1COR12-20d and COR13-29c, two different chips were 228 taken: one representative of the metasomatic marble, where silicates are present as clasts, and 229 another one representative of a Stage\#1 diopside+lawsonite rock, where carbonate is a minor 230 constituent. When an average value is indicated, the standard deviation $(1 \sigma)$ is also reported 231 (Tables 1 and S2). 
233 In/out carbon fluxes in the subducting slab (during high-pressure metamorphism) are 234 estimated from the grams of $\mathrm{CO}_{2}$ per $100 \mathrm{~g}$ of rock released by decarbonation reaction and 235 carbonate dissolution vs. the grams of $\mathrm{CO}_{2}$ per $100 \mathrm{~g}$ of rock bound by rock carbonation 236 process (Section 8.3). The $\mathrm{CO}_{2}$ bound in the rocks of this study was back calculated from 237 whole rock analyses removing the measured organic carbon content to the measured $\mathrm{CO}_{2}$ (red 238 bar in Fig. 8a, see also Table S2). Values for $\mathrm{CO}_{2}$ released per $100 \mathrm{~g}$ of rock after carbonate 239 dissolution (Ague and Nicolescu, 2014) and decarbonation of calcschists (Cook-Kollars et al., 240 2014) are taken from the literature. For the data on carbonate dissolution (Ague and 241 Nicolescu, 2014), we took the average of the estimated $\mathrm{CO}_{2}$ loss in samples from Syros 242 (35.1g) and Tinos (22.2g), thus resulting in $28.65 \mathrm{~g}$ of $\mathrm{CO}_{2}$ lost during carbonate dissolution 243 (blue bar in Fig. 8a). For samples affected by decarbonation, we took the calcschist modeled 244 by Cook-Kollars et al. (2014). This rock initially contains 40 wt.\% carbonate (i.e. the initial $245 \mathrm{CO}_{2}$ content is $17.6 \mathrm{~g}$ per 100 of rock) and it loses $50 \%$ of its initial $\mathrm{CO}_{2}$, thus $8.8 \mathrm{~g}$ per $100 \mathrm{~g}$ of 246 rock (green bar in Fig. 8a). Cook-Kollars et al. (2014) highlighted that natural samples from 247 Schist Lustrés and Cignana suite show a lower extent of decarbonation. They conclude that 248 decarbonation reactions during metamorphism may cause the loss of 10 to $20 \%$ of the initial $249 \mathrm{CO}_{2}$. We took the intermediate value of $15 \%$. Thus, considering the same initial $\mathrm{CO}_{2}$ content 250 of $17.6 \mathrm{~g}$ per $100 \mathrm{~g}$ of precursor rock, the $\mathrm{CO}_{2}$ lost is $2.64 \mathrm{~g}$ per $100 \mathrm{~g}$ of rock (orange bar in 251 Fig. 8a).

4.4 Stable isotope data

4.4.1 Carbon and Oxygen isotopes of calcite

254 Chips of carbonate were taken from hand-samples and crushed in an agate mortar. Raman and 255 SEM analyses establish that the carbonate is nearly pure Ca-carbonate. The isotopic 256 composition of calcite was measured by an AP2003 continuous flow mass spectrometer at 
LGIS, IPGP. Approximately 2 to $2.5 \mathrm{mg}$ of sample were loaded in vials; three standards of 258 pure calcite were also used for calibration of both concentration and isotopic composition. 259 After flushing with ultrapure helium, orthophosphoric acid $\left(\mathrm{H}_{3} \mathrm{PO}_{4}\right)$ was introduced in each 260 tube in order to produce gaseous $\mathrm{CO}_{2}$. After 4 hours of reaction at ambient temperature, 261 calcite completely decomposes to release $\mathrm{CO}_{2}$ (McCrea, 1950); gases were then transferred 262 into the mass spectrometer for analysis. In order to improve the precision of the 263 measurements, each analysis was repeated four times for each vial, and each sample analysed 264 twice. The isotopic ${ }^{13} \mathrm{C} /{ }^{12} \mathrm{C}$ and ${ }^{18} \mathrm{O} /{ }^{16} \mathrm{O}$ ratios are expressed using the conventional $\delta$-notation relative to PDB and SMOW international standards. The precision is $0.1 \%$ for $\delta^{13} \mathrm{C}$ and $0.2 \%$ o 266 for $\delta^{18} \mathrm{O}$. The results are reported in Table S3. When an average value is indicated, the 267 standard deviation $(1 \sigma)$ is also reported.

\subsubsection{Oxygen isotopes of clinopyroxene}

A polished sample of omphacite + carbonate vein hosted in diopside-lawsonite rock was first studied by SEM to identify zones representative of Stage\#1 diopside and Stage\#2 omphacite (Figs. 3d and S2). Aliquots of carbonate+omphacite vein were crushed $(<100 \mu \mathrm{m})$ and single crystals of omphacite were separated by handpicking under a binocular microscope. Diopsiderich protolith rock was sampled out of the vein selvage (ca. $2 \mathrm{~cm}$ from the vein) in order to 274 avoid the isotopic contribution of the vein-related omphacite rims, as checked by SEM. Rock was crushed $(<100 \mu \mathrm{m})$ and single crystals of diopside were separated by handpicking under a

276 binocular microscope. Approximately $2 \mathrm{mg}$ of omphacite and $2 \mathrm{mg}$ of diopside were analyzed 277 using laser fluorination at IPGP (Paris, France) along with UWG-2 garnet standard. 278 Analytical methods are similar to those documented in Rumble et al. (1997). The oxygen 279 isotopic ratios are reported using the international V-SMOW standard. Measurement of 280 UWG-2 garnet standard aliquots gave $2 \sigma$ external error on $\delta^{18} \mathrm{O}$ of $\pm 0.036 \%$, which is in the 
same range of in-run uncertainties for individual measurements $(<0.03 \%$ ). Measurements were duplicated for omphacite, while for diopside the material collected was not sufficient. Fractionation factors (Hoffbauer et al., 1994) were used to infer oxygen isotopes equilibrium temperature between carbonate and clinopyroxenes (Table S3.1). Estimated errors using a Monte Carlo simulation on the calculated temperatures are $30^{\circ} \mathrm{C}$ and $20^{\circ} \mathrm{C}$ for the omphacitecalcite and diopside-calcite equilibrium, respectively.

\section{Petrography of selected metasomatic marbles}

Metasomatic marbles have characteristic features that make them different from any other carbonate-bearing rocks of the Schistes Lustrés (i.e. Mesozoic impure marbles, calcschists and ophicarbonates), although they may display mineralogical and chemical variations from one to another outcrop. As an example, the matrix carbonate in these rocks systematically displays a rod-shaped habit with rods oriented at high angles to the regional schistosity or to the margin of Stage\#1 clasts in hydraulic breccias (Fig. 3b). In all but one metasomatic marble, the carbonate is a Ca-carbonate phase. Matrix carbonate is calcite, whereas aragonite was found as inclusions in garnet and apatite (see Fig. S1). Dolomite was detected in only one sample by Raman spectroscopy and it was in very small proportions compared to Cacarbonate (dolomite content below X-ray diffraction detection limit). No ankerite was observed in these rocks, whereas it is common in calcschists and ophicarbonates of the Schistes Lustrés. As Ca-carbonate is the dominant carbonate phase, we will use hereafter the term "carbonate" to indicate compositionally pure Ca-carbonate (i.e. calcite after aragonite).

In thin section, metasomatic marbles display a characteristic structure defined by carbonaterich and diopside-lawsonite-rich domains, the latter occurring as either continuous layers or isolated patches (Figs. 4b, d, e). A compositional layering is defined by the alternation of 
carbonate aggregates with diopside ( \pm lawsonite) aggregates. Calcite rods are mm-sized; 306 diopside and lawsonite grain size ranges from $\mu \mathrm{m}$ to $\mathrm{mm}$. The mineral assemblage most commonly consists of carbonate, diopside and lawsonite, with modal proportions varying from sample to sample (Fig. 4). Garnet is also present in several samples. It is found as euhedral, $\mu \mathrm{m}$ to mm-sized crystals in textural equilibrium with carbonate. Its composition 310 ranges from grossular to almandine-spessartine solid solution (Table S4). Phengite, epidote, quartz and pumpellyite (Table S5) are also present. Common accessory phases are titanite, apatite and graphite. Although such assemblages are described in calcschists in the Western

to our knowledge. Moreover, the textural and mineralogical features of these silicates indicate

315 that they resulted from intense metasomatism during their high-pressure evolution, as 316 described below.

317 For simplicity, two dominant mineralogical assemblages representative of Stage\#1 and 318 Stage\#2 rocks are distinguished, i.e. diopside + lawsonite and carbonate + omphacite, 319 respectively. As mentioned above, additional phases may be present from one sample to 320 another. The chronological relations between the two mineralogical assemblages may be 321 deciphered from the outcrop-scale down to the micro-scale. Diopside (Quadrilateral ${ }_{96.5}$ 322 Aegirine 3.5 ; classification after Morimoto, 1989; see Tab. S1) formation at high-pressure 323 conditions during subduction is demonstrated by: (i) the occurrence of diopside veins cross324 cutting lawsonite-bearing fabrics (Fig. 3d) and (ii) the fact that the diopside veins are in turn 325 cut by carbonate+omphacite veins, indicating near peak P-T metamorphic conditions. In the 326 carbonate-bearing domains, diopside in contact with carbonate shows either embayed grain 327 boundaries or newly-formed compositional coronas of omphacite (Figs. 5a; Jadeite 39.5 328 Quadrilateral $_{44.5}$ Aegirine $_{16}$; see Tab. S1). Tiny (c.a. 10-20 $\mu \mathrm{m}$ ), second generation idioblastic 329 lawsonite crystals were locally found in the carbonate. In the vein selvage, omphacite rims on 
diopside (Fig. 5b) have the same composition as omphacite growing together with carbonate

331 in the vein. In metasomatic marbles, atoll-like textures show relict diopside cores being 332 replaced by carbonate and rimmed by omphacite (Fig. 5a), the latter being in textural 333 equilibrium with the carbonate matrix. The abundance of omphacite varies from one sample 334 to another. All transitional stages from carbonate-free diopside-lawsonite rocks to carbonate335 rich rocks are depicted in Figure 4.

336 Only one sample (COR13-21d) displays a different mineralogy, composed of (in order of 337 volume abundance): calcite, actinolite, chlorite and clinopyroxene. This sample was collected 338 within a sequence of typical metasomatic marbles, and shares with them similar characteristic 339 features such as rod-shaped carbonate and Na-rich clinopyroxene coronas (aegirine-augite, $340 \mathrm{Na}-\mathrm{Fe}^{3+}$ rich clinopyroxene, see Fig. 5c) on relict diopside. Geochemical data for this sample 341 are given in Section 6.

\section{Whole rock chemical compositions}

344 Samples of metasomatic marbles were analyzed for their major and trace element bulk 345 composition (Table S2). Reference samples of Mesozoic calcschist and ophicarbonate 346 unaffected by metasomatism (i.e. far from the studied lithological boundaries and showing no 347 mineralogical or textural evidence for fluid-rock interactions), were also analyzed (Table S2). 348 Table 1 reports the average major element composition of metasomatic marble as well as the 349 compositions of a Stage\#1 diopside-lawsonite rock (sample OF3598 in Vitale Brovarone et 350 al., 2014) and a Stage\#1 rock with higher lawsonite content (lawsonite mode c.a. 75\%; 351 sample COE5, Martin et al., 2011). 
354 oxides $\mathrm{CaO}, \mathrm{MgO}, \mathrm{SiO}_{2}$ and $\mathrm{CO}_{2}$ are presented. Metasomatic marbles have variable 355 compositions based on the carbonate-silicate modal proportions (Tables 1, S2). The average 356 composition is: $\mathrm{CaO} 39$ wt. $\%( \pm 5 \%, 1 \sigma) ; \mathrm{CO}_{2} 27$ wt. $\%( \pm 6 \%, 1 \sigma)$; $\mathrm{SiO}_{2} 20$ wt.\% $( \pm 6 \%, 1 \sigma)$ 357 and $\mathrm{MgO} 3$ wt.\% $( \pm 2 \%, 1 \sigma)$. The silicate mode in sample COR13-21d is higher, thus 358 resulting in a slightly different bulk rock composition $\left(\mathrm{CaO} 22 \% ; \mathrm{CO}_{2} 12 \% ; \mathrm{SiO}_{2} 37 \%\right)$. Even 359 accounting for the lower carbonate content, sample Cor13-21d has an Mg-richer composition 360 (MgO 11 wt.\%) compared to metasomatic marbles. Comparing the average composition of metasomatic marbles with Stage\#1 diopside362 lawsonite rock (Table 1), the following features can be outlined. Despite the variability of the 363 protolith (with more or less abundant lawsonite), $\mathrm{CaO}$ is always enriched ( $\mathrm{CaO}$ in 364 metasomatic marbles is about double that in Stage\#1 rocks). $\mathrm{MgO}$ variations are more 365 difficult to evaluate, as they depend not only on the silicate content of metasomatic marbles, 366 but also on the initial diopside modal proportion of Stage\#1 rock (cf. samples OF3598 and 367 COE5, Table 1). The reference calcschist (sample COR13-32) fits the range of compositions 368 of Alpine calcschists (Busigny et al. 2003, Galvez et al., 2013b). The reference ophicarbonate 369 sample (sample COR13-30a), has a Mg-rich composition (13 wt.\% vs. 3 wt.\% in metasomatic marbles), similar to sample COR13-21d.

Whole-rock Rare-Earth Element (REE) analyses of most analyzed samples have 372 positive slopes $\left(\mathrm{La}_{N} / \mathrm{Lu}_{N}>1\right)$ comparable to the reference calcschist and the host diopside373 lawsonite rock formed at the expense of carbonate free, continental basement 374 metasedimentary rocks (Fig. 6; Martin et al., 2011; Vitale Brovarone et al., 2014). Only 375 sample COR13-21d differs significantly. It has a rather flat REE pattern, except for a slight 376 negative Ce anomaly (Fig. 6). This pattern matches reasonably well with the ophicarbonate 377 standard and passive margin serpentinites (Barnes et al., 2014; Deschamps et al., 2013; 378 Kodolányi et al., 2011). This sample also has a significantly higher Ni and Cr content than the 
other analyzed samples (1022 and 2114 ppm respectively, Table S2). These patterns suggest an ultramafic signature for this sample.

\section{Carbon and oxygen stable isotope analysis of Ca-carbonate and clinopyroxene}

$\mathrm{C}$ and $\mathrm{O}$ isotopic compositions of calcite from metasomatic marbles (including veins) were analyzes, as well as the O isotopic compositions of Stage\#1 diopside and Stage\#2 omphacite. For reference, calcite from calcschist and ophicarbonate was also analyzed. Analyses of carbon and oxygen isotopes of calcite are reported in Table S3.

For all samples (reference calcschists and ophicarbonate as well as metasomatic marbles) calcite $\delta^{13} \mathrm{C}$ values vary little and average $1.1 \%$ o $( \pm 1.2,1 \sigma)$ (Fig. 7a), consistent with marine sedimentary carbonate rocks (Plank and Langmuir, 1998). The average calcite $\delta^{18} \mathrm{O}$ value of metasomatic marbles is $14.3 \%$ o $( \pm 3.2,1 \sigma)$ (Fig. $7 \mathrm{a})$. The two reference calcschists (from ca. 8 to $50 \mathrm{~m}$ from the serpentinite, across strike) have an average $\delta^{18} \mathrm{O}$ of $21.5 \%$ o $( \pm 1.5$, $1 \sigma)$. The ophicarbonate analyzed in this study has $\delta^{18} \mathrm{O}$ of $11 \%$. Carbonate in veins cutting across carbonate-free, diopside-rich rocks has very low $\delta^{18} \mathrm{O} 10.6 \%$ of vein distance from the serpentinite. Carbonate in samples collected from outcrops with higher carbonate/silicate ratios (e.g. carbonate mode 70\%) display more dispersed values that vary from $\sim 12$ to $\sim 18 \%$. In these rocks, samples collected a few centimeters from the serpentinite body have an average value of $\sim 14 \%$ ( 9 samples), whereas the two samples collected far from the serpentinite (i.e. more than $3 \mathrm{~m}$ ) and within the analyzed interaction zone (cf. Figs. 6 and S3 and Table S3 for sample location and respective REE patterns and isotope composition) have a heavier signature of $\sim 18 \%$. A simple correlation cannot be established between the distance from the serpentinite and the $\delta^{18} \mathrm{O}$ values within the reaction zone. Indeed, Stage\#2 omphacite-carbonate veins far from the serpentinite body (up to $8 \mathrm{~m}$ 
403 from the contact) have low $\delta^{18} \mathrm{O}$ values similar to metasomatic marble sampled a few $\mathrm{cm}$ from 404 the serpentinite body (e.g. samples 2COR14-4i and 1COR14-11a; Table S3). However, taken 405 as a whole, metasomatic marbles, overlying the serpentinite body, have lower $\delta^{18} \mathrm{O}$ compared 406 to the reference calcschists. Indeed, calcschists that lack the petrographic characteristics of 407 intense fluid-rock interaction present in metasomatic marbles always have heavier values (ca. 408 21\%o, see samples COR13-32 and 1COR12-11Q, Table S3), even if they crop out at less than $4091 \mathrm{~m}$ from the metasomatic zones.

Reconnaissance oxygen isotope measurements on silicate minerals were performed in 411 order to test for isotopic equilibrium between the two clinopyroxene generations (Stage\#1 412 diopside and Stage\#2 omphacite) and the vein infill carbonate. The analyzed sample is 413 composed of the host Stage\#1 diopside-rich rock cut across by a Stage\#2 calcite-omphacite 414 vein (Figs. 3d and S2). Diopside has $\delta^{18} \mathrm{O}$ values of $\sim 6 \%$. Vein infill omphacite has heavier $415 \delta^{18} \mathrm{O}$ of $\sim 7 \%$. Fractionation factors available from literature data $\left(\Delta_{\text {calcite-clinopyroxene from }}\right.$ 416 Hoffbauer et al., 1994, , Table S3.1), give equilibrium temperature of $494^{\circ} \mathrm{C}\left( \pm 30^{\circ}\right)$ for the 417 omphacite-carbonate assemblage and $426^{\circ} \mathrm{C}\left( \pm 20^{\circ}\right)$ for diopside-carbonate using the same 418 database. These differing temperatures are consistent with textural disequilibrium between the 419 mineral pairs (carbonate-diopside and diopside-omphacite). The omphacite-calcite 420 thermometer yields temperatures closer to the estimated peak $T$ conditions of the 421 metamorphic unit $\left(490-530^{\circ} \mathrm{C}\right.$, see Section 2$)$. This observation suggests isotopic equilibrium 422 for the omphacite + carbonate paragenesis and confirms the microtextural observations (see 423 Section 5).

Equilibrium was likely reached by fluid-mediated reactions. However, this 425 interpretation must be taken with caution because only one sample was analyzed. The 426 composition of an aqueous fluid in equilibrium with these minerals was also calculated at 500 $427{ }^{\circ} \mathrm{C}$ (i.e. near peak conditions). The $\delta^{18} \mathrm{O}$ of a fluid in equilibrium with the measured $\mathrm{Ca}$ - 
carbonate is $10.1 \%$ ( $\Delta_{\text {cal-H2O }}=0.62$, Zheng et al. 1994). For the analyzed omphacite composition, the water $\delta^{18} \mathrm{O}$ obtained is $8.4 \%$ o $\left(\Delta_{\mathrm{di}-\mathrm{H} 2 \mathrm{O}}=-1.95, \Delta_{\mathrm{ae}-\mathrm{H} 2 \mathrm{O}}=-0.07\right.$ and $\Delta_{\mathrm{jd}-\mathrm{H} 2 \mathrm{O}}=-0.14$, Zheng et al., 1993). Although the fractionation factors for lawsonite are not available, the

431 diopside-water equilibrium, can be used as a proxy for fluid in equilibrium with the Stage\#1 432 assemblage implying that the fluid $\delta^{18} \mathrm{O}=8 \%$. The mismatch between calcite-water and omphacite-water oxygen composition equilibrium is quite small as well as for water in

434 equilibrium with diopside. It is worth noting that the estimated fluid composition is similar for 435 both metasomatic stages.

\section{DISCUSSION}

\subsection{Fluid-mediated carbonation at high-pressure conditions}

439 Detecting metasomatism in metasedimentary rocks is often challenging owing to the 440 variability of protolith compositions (Bebout and Burton, 1989; Ague, 2003). The occurrence 441 of carbonate in metasedimentary rock is common, and in most cases likely reflects the 442 primary composition of the subducted rocks. However, the direct spatial association of 443 Stage\#2 metasomatic marbles along major fluid conduits characterized by intense 444 metasomatism (Martin et al., 2011; Vitale Brovarone et al., 2014) suggests that the evolution 445 of these rocks was mediated by the interaction with external fluids (e.g. Ague, 2003). Rod-shaped calcite crystals in marbles from eclogite-facies terrains have been 447 described in Syros (Greece) and the Sivrihisar belt (Turkey) (Brady et al., 2004; Seaton et al., 448 2009), and have been interpreted as topotactic pseudomorphs of calcite after aragonite. Both 449 studies regard carbonate as a primary constituent of the rock and do not consider fluid450 mediated precipitation. In the study case, we consider this hypothesis unlikely based on 
several lines of evidence. Textures like crack-seal and networked carbonate veins cutting

452 across carbonate-free metasomatic rocks suggest high pore fluid pressure and hydrofracturing

453 (e.g. Bebout and Barton, 1989). This evidence clearly points to the percolation of carbonic

454 fluids along lithological boundaries, and their precipitation of carbonate. As reported in

455 Sections 2 and 5, field relations and microstructural features (Figs. 4) suggest carbonation of

456 the Ca-Mg-rich silicate rocks. The lateral (along schistosity) transition from carbonate-free

457 diopside-lawsonite rocks and metasomatic marbles is evidence for chemical interaction

458 occurring between a carbonic fluid and the host-rock assemblage. Progressive replacement of

459 diopside-rich rocks by carbonate is demonstrated at the microscale by the corroded texture of 460 precursor minerals (embayed and atoll-like diopside, Figs. 4d, e and 5a) and producing 461 coronas in contact with carbonates (e.g. omphacite rims on diopside, Figs. 5a and b). The 462 carbonate isotopic composition presented in this work (Section 7) further supports the 463 hypothesis of fluid-mediated carbonate precipitation. All metasomatic marbles are composed 464 of Ca-carbonate (calcite after aragonite). This appears unlikely in the case of metamorphic 465 recrystallization of rocks containing significant whole rock $\mathrm{Mg}$ (Table S2). These 466 observations suggest that carbonate precipitation occurred via two concurrent processes of 467 fluid-rock interaction: crack-sealing (carbonation by volume increase, Section 3) and mineral 468 replacement (Section 5). Note that carbonation of mafic rocks during high-pressure 469 metamorphism was also suggested by Boundy et al. (2002) for eclogite-facies rocks from the 470 Lindås Nappe (Caledonides, Western Norway) and by Kleine et al. (2014) for blueschist471 facies rocks from Syros. Both authors proposed carbonation of mafic eclogites along a shear 472 zone affected by fluid circulation. Similarly, Nishiyama (1990) proposed metamorphic 473 carbonation during exhumation of blueschist-facies metabasic rocks in association with 474 serpentinites in the Nishisonogi metamorphic complex (Japan). 
475 Based on these observations, the metasomatic history of the Corsican eclogite-facies marbles 476 can be subdivided into two stages, both occurring at high-pressure conditions during 477 subduction.

478 Stage\#1: calcic metasomatism of protolith metasedimentary rocks or continental basement 479 transforms metasediments in contact with serpentinites to $\mathrm{Ca}-\mathrm{Mg}$ rocks dominantly composed 480 of diopside and lawsonite during prograde metamorphism (cf. Martin et al., 2011; Vitale 481 Brovarone et al., 2014).

482 Stage\#2: carbon-bearing fluid reacts with the pre-existing diopside-lawsonite rock and 483 associated serpentinites leading to the precipitation of carbonate-dominated assemblages as

484 either crack-filling material, or by replacing silicate minerals. The metamorphic conditions for 485 this stage are constrained to high-pressure conditions by the assemblage aragonite + 486 omphacite + lawsonite + garnet that characterize several of the analyzed samples $(\mathrm{P}>1.5$ $487 \mathrm{GPa}$ at $450-500{ }^{\circ} \mathrm{C}$ ), and supported by the estimated $\mathrm{O}$ isotope Ca-carbonate-omphacite 488 equilibrium $\mathrm{T}$ of ca. $500^{\circ} \mathrm{C}$.

\subsection{Stable isotopes: marker of rock carbonation and fluid source?}

490 Stable isotope geochemistry has provided important information for the study of high491 pressure metasomatic processes involving carbonates (Valley 1986; Wang \& Rumble 1999; 492 Ague and Nicolescu, 2014; Galvez et al., 2013a,b). The trends of decreasing $\delta^{13} \mathrm{C}$ and $\delta^{18} \mathrm{O}$ 493 isotopic composition of the metamorphic carbonates may be attributed to: (i) inheritance of 494 protolith isotopic signatures (Wang and Rumble, 1999), (ii) carbonate-silicate isotopic 495 exchange; (iii) devolatilization reactions driven by increasing temperatures (Wang and 496 Rumble, 1999), or (iv) interaction with COH fluids (Ague and Nicolescu, 2014; Galvez et al., 497 2013a,b). 
In this study, hypothesis (i) can be ruled out by comparison of the isotopic signature of metasomatic marbles with calcschists far from the metasomatic zones. The reference calcschists have $\delta^{13} \mathrm{C}$ values of ca. $0 \%$ and $\delta^{18} \mathrm{O}$ of ca. $21 \%$ similar to those of calcschists and carbonate veins (for similar metamorphic conditions) in Alpine Corsica (Cartwright and Buick, 2000; Miller et al., 2001), Western Alps (Cartwright and Barnicoat, 1999; CookKollars et al., 2014), and Cyclades (Ague and Nicolescu, 2014) (Fig. 7a). The metasomatic marble $\delta^{13} \mathrm{C}$ values are shifted toward heavier values, although still overlapping the compositional range of seawater carbonates, whereas $\delta^{18} \mathrm{O}$ values display a much greater dispersion towards lower values (Fig. 7a).

Partial silicate-carbonate oxygen isotope exchange (hypothesis ii) is an alternative way to explain low $\delta^{18} \mathrm{O}$ (with almost no change in $\delta^{13} \mathrm{C}$ ). We discard this scenario for two reasons. 1) At temperatures of $500^{\circ} \mathrm{C}$, isotopic exchange by diffusion between two solid 510 phases is expected to be very slow and thus restricted to grain margins. 2) Even if interface511 coupled dissolution precipitation allowed faster isotopic exchange (Putnis and John, 2010), 512 the $\delta^{18} \mathrm{O}$ achieved in the carbonate after such equilibration should be correlated with the 513 silicate content (the lowest $\delta^{18} \mathrm{O}$ being observed for the highest silicate content; Wang and 514 Rumble 1999; Cook-Kollars et al. 2014). Figure 7b shows that no correlation exists between 515 the $\delta^{18} \mathrm{O}$ of carbonate and the silicate content in the rock.

As a test for the third hypothesis, the metasomatic marbles are compared with 517 carbonates that have experienced devolatilization reactions. Carbonates in skarns formed by 518 contact metamorphism are characterized by a strong decrease of $\delta^{13} \mathrm{C}$ coupled with a smaller $519 \delta^{18} \mathrm{O}$ decrease during decarbonation (e.g. Valley 1986). The trend observed in Corsican 520 metasomatic marbles of $\delta^{18} \mathrm{O}$ decreasing with $\delta^{13} \mathrm{C}$ remaining constant is actually different 521 from a devolatilization trend (Fig. 7c). 

interactions between rocks and $\mathrm{COH}$ fluids (hypothesis iv) is considered the most likely hypothesis. Galvez et al. (2013b) reported carbonate reduction to graphite in contact with serpentinites in the high-pressure units of Alpine Corsica. In this study, carbonates display a peculiar variation showing a decreasing $\delta^{18} \mathrm{O}$ coupled with increasing $\delta^{13} \mathrm{C}$. Residual carbonate in samples affected by carbonate dissolution driven by serpentinite-derived fluids described by Ague and Nicolescu (2014) show a drop in oxygen isotopic signature compared to the protolith (6 to $10 \%$ lower values). However, changes in $\delta^{13} \mathrm{C}$ are very small, with only a $1.5 \%$ decrease. Both carbonate precipitation and dissolution seem to be characterized by a

531 large decrease in $\delta^{18} \mathrm{O}$ and little to no change in $\delta^{13} \mathrm{C}$ (Fig. 7c; cf. Section 8.3 for additional 532 discussion). The $\delta^{13} \mathrm{C}$ values of metasomatic marbles are similar to those typical of carbonates 533 in marine sediments (e.g. Hoefs, 2013) and subducted oceanic suites $\left(\delta^{13} \mathrm{C}\right.$ close to $0 \%$; e.g. 534 Miller et al., 2001), thus indicating that carbon in the fluids derives from marine carbonates, 535 likely from the overlying carbonate-bearing metasedimentary rocks. The low $\delta^{18} \mathrm{O}$ values 536 rather point to fluids equilibrated with silicates in mafic or ultramafic rocks, possibly 537 including Stage\#1 metasomatic rocks (Miller et al., 2001; Martin et al., 2014; Vitale 538 Brovarone et al., 2014; Angiboust et al., 2014). The large serpentinite body in contact with 539 the rocks of this study would represent a plausible source for aqueous fluid with a light 540 oxygen signature. Despite the lack of evidence for serpentinite dehydration (e.g. metamorphic 541 olivine) in the samples from Alpine Corsica, a growing number of studies (Faccenda 2014; 542 Wilson et al., 2014) have proposed that fluids generated at depth can move up along the plate 543 interface and interact with shallower slab-forming rocks. Ague and Nicolescu (2014) 544 proposed that fluid equilibrated with mafic and ultramafic rocks can drive stoichiometric 545 carbonate dissolution, resulting in aqueous fluid enriched in carbon with $\delta^{13} \mathrm{C}$ around $0 \%$. 546 However, if fluids were diluted, the contribution of oxygen from dissolved carbonates to the 
oxygen isotopic signature of the fluid is expected to be very low. The preservation of lawsonite requires very low $\mathrm{X}_{\mathrm{CO} 2}$ fluid concentrations $\left(\mathrm{X}_{\mathrm{CO} 2}<0.005\right.$; e.g. Nitsh, 1972), demonstrating that the carbon-bearing fluid was dominantly aqueous. Altogether, these considerations point to metasomatic marbles formation by interaction with aqueous fluids bringing isotopic signatures of both dissolved carbonates and mafic/ultramafic reservoirs.

\subsection{Rock carbonation during subduction: implications for the deep carbon cycle}

The behavior of carbonate, more specifically Ca-carbonate, during subduction has long been a matter of debate. Few experimental studies of Ca-carbonate solubility in $\mathrm{H}_{2} \mathrm{O}$ have been conducted at P-T conditions appropriate for subduction metamorphism (Walther and Long, 1986; Fein and Walther, 1989; Newton and Manning, 2002; Caciagli and Manning, 2003; Manning et al., 2013; Facq et al., 2014). Caciagli and Manning (2003) showed that calcite solubility increases with $\mathrm{P}$ and $\mathrm{T}$ at high-pressure conditions. Ca-carbonate dissolution at high-pressure conditions has been demonstrated to be very efficient in natural environments (P > 2 GPa, Frezzotti et al., 2011; Ague and Nicolescu, 2014), and it is now considered as a major process for the mobilization of carbon in subduction zones (Kelemen \& Manning, 2015). Carbonic fluids produced by carbonate dissolution are thus a potential source of carbon for carbonate precipitation in subduction zones. Figure $8 \mathrm{a}$ shows a rough carbon fluxes mass balance (see Section 4.3 for method of carbon fluxes calculation) considering carbon bound by rock carbonation in metasomatic marbles vs. the amount of carbon dioxide released by dissolution and devolatilization reactions estimated in previous field-based studies in analog geological settings (Ague and Nicolescu, 2014; Cook-Kollars et al., 2014). The amount of $\mathrm{CO}_{2}$ released by decarbonation (green and orange bars) is small compared to that released by dissolution (blue bar). Consequently, processes related to carbonate solubility 
mobilize carbon in greater quantities than simple decarbonation reactions (Ague and

572 Nicolescu, 2014). A possible explanation for this result is that devolatilization reactions are controlled and limited by the presence of silicate phases with which the carbonate minerals can react, regardless of the fluid fluxes. The red bar in the diagram indicates the inferred amount of $\mathrm{CO}_{2}$ transferred from the fluid to the rock by rock carbonation, considering an 576 initial carbon content of $0 \mathrm{~g}$ per $100 \mathrm{~g}$ of precursor rock. The amount of carbon bound per $577100 \mathrm{~g}$ of rock is directly comparable with that released by carbonate dissolution. This observation suggests that a large amount of dissolved carbon can be re-bound into the solid phase by rock carbonation, and that carbonate dissolution and rock carbonation at highpressure conditions are both crucial processes controlling carbon fluxes during subduction.

581 Slab-parallel ascent of fluids may represent a suitable configuration to enhance the efficiency 582 of rock-carbonation reactions, if favorable conditions occur (Lazar et al., 2014; Kelemen and 583 Manning, 2015; Sverjensky et al., 2014). Figure 8b shows the Ca-carbonate solubility in 584 aqueous fluid as a function of $\mathrm{P}$ and $\mathrm{T}$ (after Kelemen \& Manning 2015) along with the 585 predicted P-T path for cold subduction (after Syracuse et al., 2010). Deep metamorphic fluids 586 ascending parallel to the downgoing slab would cut across the solubility curves during their 587 ascent. Although prediction of fluid slab-parallel ascent by numerical modeling is still limited 588 (e.g. Faccenda, 2014; Wilson et al., 2014), natural samples from high-pressure (this study) 589 and ultrahigh-pressure exhumed metamorphic terrains may preserve records of the 590 interactions of deep-fluids with the slab-forming rocks. In this study, it is shown how major 591 lithological interfaces (e.g. crust-metasediments) may represent ideal settings for fluid 592 channelization. In addition, the data presented here also show that Ca-Mg-rich rocks 593 (diopside-rich) and ultramafic rocks are reactive lithologies for rock carbonation at high594 pressure conditions. 
596 possible lithological configuration for rock carbonation. High amounts of carbonic fluids 597 resulting from slab carbonate dissolution are expected to percolate through the mantle wedge, 598 where ultramafic rocks may represent a suitable reactant (Kelemen and Manning 2015). 599 Based on the current knowledge of processes occurring along the plate interface (e.g. 600 Syracuse et al., 2010), carbonation of the hydrated mantle wedge overlying subducting slabs 601 seems unlikely in the case of vertical upward migration (rising T), whereas it is more 602 plausible along the slab-mantle interface (decreasing T). Exhumation of cold serpentinite 603 diapirs in forearc settings may also be a possible environment for rock carbonation (Fryer, 604 1992). Future studies on rocks ascribed to the mantle wedge are needed to test this hypothesis.

\section{Conclusions}

606 The petrological and geochemical results of this study indicate that the Corsican eclogite607 facies marbles found along major fluid conduits have a metasomatic origin and were formed 608 at high-pressure conditions during subduction. These rocks formed by carbonation of $\mathrm{Ca}-\mathrm{Mg}$ 609 silicate rocks by percolating carbonic fluids (Fig. 9). This implies that carbonic fluids formed 610 during prograde carbonate dissolution may not be directly and fully transferred to the mantle 611 wedge, but can also flow along slab interfaces (i.e. crust-metasediments) and reprecipitate 612 carbonates under favorable conditions in both slab- and mantle-forming rocks. Carbonates 613 precipitating from these fluids then display a characteristic geochemical and isotopic 614 signature. Therefore, carbonation of $\mathrm{Ca}-\mathrm{Mg}$ silicate rocks at high-pressure-low temperature 615 conditions can be an efficient process to lock carbon in the rock, as is well documented at 616 shallow and seafloor conditions (Guyot et al., 2011; Matter and Kelemen, 2009). The 617 widespread occurrence of these rocks in the units of Alpine Corsica is likely a consequence of 618 the overall exceptional preservation of pristine high-pressure-low temperature assemblages in 619 this belt. This suggests that analogous rocks and processes may have occurred in more 
retrogressed high-pressure belts, such as the Western Alps, the Cyclades and Turkey, and may

621 be happening today in present-day subduction zones as well.

Whether or not high-pressure rock carbonation permanently binds carbon in the rock

623

cannot be easily established at present. For example, high-pressure carbonated rocks can experience successive carbonate dissolution in deeper parts of subduction zones. Nonetheless, carbonation of slab- and mantle-forming rocks (Fig. 9) likely modulates the residence time of carbon in different reservoirs, and can modify the oxygen and carbon isotopic signature of carbonates in subduction zones. Considering a longer time-scale perspective (e.g. time elapsed from subduction initiation to continental collision), carbonation at high-pressure conditions may ultimately influence the fluctuation of $\mathrm{CO}_{2}$ emissions at volcanic arcs during the life of a subduction zone, and thereby the fluctuation of atmospheric $\mathrm{CO}_{2}$ over geological time scales (e.g. Berner \& Kothavala, 2001).

Acknowledgment: The research leading to these results has received funding from the Deep Carbon Observatory, the University Pierre et Marie Curie (Paris 6) and Sorbonne Universités. Imène Esteve and Sébastien Charron are thanked for their technical support in the SEM platform. Benoit Baptiste is thanked for his technical support in the XRD platform. Scanning Electron Microscope (SEM) facility of the Institut de Mineralogie, Physique des Materiaux et Cosmochimie is supported by Région Ile de France grant SESAME 2006 N_ I-07-593/R, INSU-CNRS, INP-CNRS, University Pierre et Marie Curie - Paris 6, and by the French National Research Agency (ANR) grant no. ANR-07-BLAN-0124-01. Michel Fialin and Nicolas Rividi (CAMPARIS service) are thanked for their technical support during EMPA measurement.

\section{References}

Ague, J.J., 2003. Fluid Infiltration and Transport of Major, Minor, and Trace Elements During Regional Metamorphism of Carbonate Rocks, Wepawaug Schist, Connecticut, USA. American Journal of Science 303, 753-816. doi:10.2475/ajs.303.9.753

Ague, J.J., Nicolescu, S., 2014. Carbon dioxide released from subduction zones by fluid-mediated reactions. Nature Geosci 7, 355-360. 
Alt, J.C., Teagle, D.A.H., 1999. The uptake of carbon during alteration of ocean crust. Geochimica et Cosmochimica Acta 63, 1527-1535. doi:10.1016/S0016-7037(99)00123-4

Angiboust, S., Pettke, T., De Hoog, J.C.M., Caron, B., Oncken, O., 2014. Channelized Fluid Flow and Eclogitefacies Metasomatism along the Subduction Shear Zone. Journal of Petrology 55, 883-916. doi:10.1093/petrology/egu010

Bach, W., Rosner, M., Jöns, N., Rausch, S., Robinson, L.F., Paulick, H., Erzinger, J., 2011. Carbonate veins trace seawater circulation during exhumation and uplift of mantle rock: Results from ODP Leg 209. Earth and Planetary Science Letters 311, 242-252. doi:10.1016/j.eps1.2011.09.021

Barnes, J.D., Beltrando, M., Lee, C.-T.A., Cisneros, M., Loewy, S., Chin, E., 2014. Geochemistry of Alpine serpentinites from rifting to subduction: A view across paleogeographic domains and metamorphic grade. Chemical Geology 389, 29-47. doi:10.1016/j.chemgeo.2014.09.012

Bebout, G.E., Barton, M.D., 1989. Fluid flow and metasomatism in a subduction zone hydrothermal system: Catalina Schist terrane, California. Geology 17, 976-980.

Beltrando, M., Manatschal, G., Mohn, G., Dal Piaz, G.V., Vitale Brovarone, A., Masini, E., 2014. Recognizing remnants of magma-poor rifted margins in high-pressure orogenic belts: The Alpine case study. EarthScience Reviews 131, 88-115. doi:10.1016/j.earscirev.2014.01.001

Berner, R.A., Kothavala, Z., 2001. GEOCARB III: a revised model of atmospheric CO2 over Phanerozoic time. American Journal of Science 301, 182-204.

Boundy, T.M., Donohue, C.L., Essene, E.J., Mezger, K., Austrheim, H., 2002. Discovery of eclogite facies carbonate rocks from the Lind la as Nappe, Caledonides, Western Norway. Journal of Metamorphic Geology 20, 649-667.

Bowman, J.R., Valley, J.W., Kita, N.T., 2009. Mechanisms of oxygen isotopic exchange and isotopic evolution of 180/16O-depleted periclase zone marbles in the Alta aureole, Utah: insights from ion microprobe analysis of calcite. Contributions to Mineralogy and Petrology 157, 77-93. doi:10.1007/s00410-0080321-1

Brady, J.B., Markley, M.J., Schumacher, J.C., Cheney, J.T., Bianciardi, G.A., 2004. Aragonite pseudomorphs in high-pressure marbles of Syros, Greece. Journal of Structural Geology 26, 3-9. doi:10.1016/S01918141(03)00099-3

Caciagli, N.C., Manning, C.E., 2003. The solubility of calcite in water at $6-16 \mathrm{kbar}$ and $500-800^{\circ} \mathrm{C}$. Contributions to Mineralogy and Petrology 146, 275-285. doi:10.1007/s00410-003-0501-y

Cartwright, I., Barnicoat, C.A., 1999. Stable isotope geochemistry of Alpine ophiolites: a window to ocean-floor hydrothermal alteration and constraints on fluid-rock interaction during high-pressure metamorphism. International Journal of Earth Sciences 88, 219-235. doi:10.1007/s005310050261

Cartwright, I., Buick, I.S., 2000. Fluid generation, vein formation and the degree of fluid-rock interaction during decompression of high-pressure terranes: the Schistes Lustrés, Alpine Corsica, France. Journal of Metamorphic Geology 18, 607-624.

Connolly, J.A.D., 2005. Computation of phase equilibria by linear programming: A tool for geodynamic modeling and its application to subduction zone decarbonation. Earth and Planetary Science Letters 236, 524-541. doi:10.1016/j.eps1.2005.04.033

Cook-Kollars, J., Bebout, G.E., Collins, N.C., Angiboust, S., Agard, P., 2014. Subduction zone metamorphic pathway for deep carbon cycling: I. Evidence from HP/UHP metasedimentary rocks, Italian Alps. Chemical Geology 386, 31-48. doi:10.1016/j.chemgeo.2014.07.013

Deschamps, F., Godard, M., Guillot, S., Hattori, K., 2013. Geochemistry of subduction zone serpentinites: A review. Lithos 178, 96-127. doi:10.1016/j.lithos.2013.05.019

Faccenda, M., 2014. Water in the slab: A trilogy. Tectonophysics 614, 1-30. doi:10.1016/j.tecto.2013.12.020

Facq, S., Daniel, I., Montagnac, G., Cardon, H., Sverjensky, D.A., 2014. In situ Raman study and thermodynamic model of aqueous carbonate speciation in equilibrium with aragonite under subduction zone conditions. Geochimica et Cosmochimica Acta 132, 375-390. doi:10.1016/j.gca.2014.01.030

Fein, J., Walther, J., 1989. Calcite solubility and speciation in supercritical $\mathrm{NaCl}-\mathrm{HCl}$ aqueous fluids. Contr. Mineral. and Petrol. 103, 317-324. doi:10.1007/BF00402918

Fournier M., Jolivet, L., Goff, B., Dubois, R., 1991. Alpine Corsica metamorphic core complex. Tectonics 10, 1173-1186

Frezzotti, M.L., Selverstone, J., Sharp, Z.D., Compagnoni, R., 2011. Carbonate dissolution during subduction revealed by diamond-bearing rocks from the Alps. Nature Geoscience 4, 703-706. doi:10.1038/ngeo1246

Fryer, P., Pearce, J.A., Stokking, L.B., others, 1992. 36. A synthesis of Leg 125 drilling of serpentine seamounts on the Mariana and Izu-Bonin forearcs, in: Proceedings of the Ocean Drilling Program, Scientific Results. pp. 593-614. 
Galvez, M.E., Beyssac, O., Martinez, I., Benzerara, K., Chaduteau, C., Malvoisin, B., Malavieille, J., $2013 a$. Graphite formation by carbonate reduction during subduction. Nature Geoscience 6, 473-477. doi:10.1038/ngeo 1827

Galvez, M.E., Martinez, I., Beyssac, O., Benzerara, K., Agrinier, P., Assayag, N., 2013b. Metasomatism and graphite formation at a lithological interface in Malaspina (Alpine Corsica, France). Contributions to Mineralogy and Petrology 166, 1687-1708. doi:10.1007/s00410-013-0949-3

Gerdes, M.L., Baumgartner, L.P., Person, M., Rumble, D., 1995. One-and two-dimensional models of fluid flow and stable isotope exchange at an outcrop in the Adamello contact aureole, Southern Alps, Italy. American Mineralogist 80, 1004-1019.

Gerdes, M.L., Baumgartner, L.P., Valley, J.W., 1999. Stable isotopic evidence for limited fluid flow through dolomitic marble in the Adamello contact aureole, Cima Uzza, Italy. Journal of Petrology 40, 853-872.

Gorman, P.J., Kerrick, D.M., Connolly, J.A.D., 2006. Modeling open system metamorphic decarbonation of subducting slabs: METAMORPHIC DECARBONATION. Geochemistry, Geophysics, Geosystems 7, n/a-n/a. doi:10.1029/2005GC001125

Guyot, F., Daval, D., Dupraz, S., Martinez, I., Ménez, B., Sissmann, O., 2011. CO2 geological storage: The environmental mineralogy perspective. Comptes Rendus Geoscience 343, 246-259. doi:10.1016/j.crte.2010.12.007

Hoefs, J., 2013. Stable isotope geochemistry. Springer Science \& Business Media.

Hoffbauer, R., Hoernes, S., Fiorentini, E., 1994. Oxygen isotope thermometry based on a refined increment method and its application to granulite-grade rocks from Sri Lanka. Precambrian Research 66, 199-220. doi:10.1016/0301-9268(94)90051-5

Jébrak, M., 1997. Hydrothermal breccias in vein-type ore deposits: A review of mechanisms, morphology and size distribution. Ore Geology Reviews 12, 111-134. doi:10.1016/S0169-1368(97)00009-7

Jolivet, L., Daniel, J.-M., Fournier, M., 1991. Geometry and kinematics of extension in Alpine Corsica. Earth and Planetary Science Letters 104, 278-291. doi:10.1016/0012-821X(91)90209-Z

Jolivet, L., Dubois, R., Fournier, M., Goffé, B., Michard, A., Jourdan, C., 1990. Ductile extension in alpine Corsica. Geology 18, 1007-1010. doi:10.1130/0091-7613(1990)018<1007:DEIAC >2.3.CO;2

Kelemen, P.B., Manning, C.E., 2015. Reevaluating carbon fluxes in subduction zones, what goes down, mostly comes up. Proceedings of the National Academy of Sciences 201507889. doi:10.1073/pnas.1507889112

Kerrick, D.M., Connolly, J.A.D., 2001. Metamorphic devolatilization of subducted marine sediments and the transport of volatiles into the Earth's mantle. Nature 411, 293-296.

Kleine, B.I., Skelton, A.D.L., Huet, B., Pitcairn, I.K., 2014. Preservation of Blueschist-facies Minerals along a Shear Zone by Coupled Metasomatism and Fast-flowing CO2-bearing Fluids. Journal of Petrology 55, 1905-1939. doi:10.1093/petrology/egu045

Kodolanyi, J., Pettke, T., Spandler, C., Kamber, B.S., Gmeling, K., 2012. Geochemistry of Ocean Floor and Fore-arc Serpentinites: Constraints on the Ultramafic Input to Subduction Zones. Journal of Petrology 53, 235-270. doi:10.1093/petrology/egr058

Lazar, C., Zhang, C., Manning, C.E., Mysen, B.O., 2014. Redox effects on calcite-portlandite-fluid equilibria at forearc conditions: Carbon mobility, methanogenesis, and reduction melting of calcite. American Mineralogist 99, 1604-1615. doi:10.2138/am.2014.4696

Malavieille, Chemenda, Larroque, 1998. Evolutionary model for Alpine Corsica: mechanism for ophiolite emplacement and exhumation of high-pressure rocks. Terra Nova 10, 317-322. doi:10.1046/j.13653121.1998.00208.x

Malvoisin, B., Chopin, C., Brunet, F., Galvez, M.E., 2012. Low-temperature Wollastonite Formed by Carbonate Reduction: a Marker of Serpentinite Redox Conditions. Journal of Petrology 53, 159-176. doi:10.1093/petrology/egr060

Manning, C.E., Shock, E.L., Sverjensky, D.A., 2013. The Chemistry of Carbon in Aqueous Fluids at Crustal and Upper-Mantle Conditions: Experimental and Theoretical Constraints. Reviews in Mineralogy and Geochemistry 75, 109-148. doi:10.2138/rmg.2013.75.5

Martin, L.A.J., Rubatto, D., Crépisson, C., Hermann, J., Putlitz, B., Vitale-Brovarone, A., 2014. Garnet oxygen analysis by SHRIMP-SI: Matrix corrections and application to high-pressure metasomatic rocks from Alpine Corsica. Chemical Geology 374-375, 25-36. doi:10.1016/j.chemgeo.2014.02.010

Martin, L.A.J., Rubatto, D., Vitale Brovarone, A., Hermann, J., 2011. Late Eocene lawsonite-eclogite facies metasomatism of a granulite sliver associated to ophiolites in Alpine Corsica. Lithos 125, 620-640. doi:10.1016/j.lithos.2011.03.015

Matter, J.M., Kelemen, P.B., 2009. Permanent storage of carbon dioxide in geological reservoirs by mineral carbonation. Nature Geosci 2, 837-841. doi:10.1038/ngeo683

McCrea, J.M., 1950. On the Isotopic Chemistry of Carbonates and a Paleotemperature Scale. The Journal of Chemical Physics 18, 849. doi:10.1063/1.1747785 
Miller, J.A., Cartwright, I., Buick, I.S., Barnicoat, A.C., 2001. An O-isotope profile through the HP-LT Corsican ophiolite, France and its implications for fluid flow during subduction. Chemical Geology 178, 43-69.

Molina, J.F., Poli, S., 2000. Carbonate stability and fluid composition in subducted oceanic crust: an experimental study on H2O-CO2-bearing basalts. Earth and Planetary Science Letters 176, 295-310. doi:10.1016/S0012-821X(00)00021-2

Molli, G., Malavieille, J., 2011. Orogenic processes and the Corsica/Apennines geodynamic evolution: insights from Taiwan. Int J Earth Sci (Geol Rundsch) 100, 1207-1224. doi:10.1007/s00531-010-0598-y

Morimoto, N., 1988. Nomenclature of Pyroxenes. Mineralogy and Petrology 39, 55-76. doi:10.1007/BF01226262

Newton, R.C., Manning, C.E., 2002. Experimental determination of calcite solubility in $\mathrm{H} 2 \mathrm{O}-\mathrm{NaCl}$ solutions at deep crust/upper mantle pressures and temperatures: Implications for metasomatic processes in shear zones. American Mineralogist 87, 1401-1409.

Nishiyama, T., 1990. CO2-metasomatism of a metabasite block in a serpentine melange from the Nishisonogi metamorphic rocks, southwest Japan. Contributions to Mineralogy and Petrology 104, 35-46.

Nitsch, K.-H., 1972. The P-T-X $\mathrm{CO}_{2}$ Stabilitätsfeld von Lawsonit. Contributions to Mineralogy and Petrology 34, 116-134. doi:10.1007/BF00373768

Poli, S., 2015. Carbon mobilized at shallow depths in subduction zones by carbonatitic liquids. Nature Geoscience 8, 633-636. doi:10.1038/ngeo2464.

Poli, S., Franzolin, E., Fumagalli, P., Crottini, A., 2009. The transport of carbon and hydrogen in subducted oceanic crust: An experimental study to $5 \mathrm{GPa}$. Earth and Planetary Science Letters 278, 350-360. doi:10.1016/j.epsl.2008.12.022

Putnis, A., John, T., 2010. Replacement Processes in the Earth's Crust. Elements 6, 159-164. doi:10.2113/gselements.6.3.159

Ravna, E.J.K., Andersen, T.B., Jolivet, L., De Capitani, C., 2010. Cold subduction and the formation of lawsonite eclogite - constraints from prograde evolution of eclogitized pillow lava from Corsica. Journal of Metamorphic Geology 28, 381-395. doi:10.1111/j.1525-1314.2010.00870.x

Rumble III, D., Farquhar, J., Young, E.D., Christensen, C.P., 1997. In situ oxygen isotope analysis with an excimer laser using F2 and BrF5 reagents and $\mathrm{O} 2$ gas as analyte. Geochimica et Cosmochimica Acta 61, 4229-4234. doi:10.1016/S0016-7037(97)00232-9

Seaton, N.C.A., Whitney, D.L., Teyssier, C., Toraman, E., Heizler, M.T., 2009. Recrystallization of highpressure marble (Sivrihisar, Turkey). Tectonophysics 479, 241-253. doi:10.1016/j.tecto.2009.08.015

Sun, S., McDonough, W.F., 1989. Chemical and isotopic systematics of oceanic basalts: implications for mantle composition and processes. Geological Society, London, Special Publications 42, 313-345. doi:10.1144/GSL.SP.1989.042.01.19

Sverjensky, D.A., Stagno, V., Huang, F., 2014. Important role for organic carbon in subduction-zone fluids in the deep carbon cycle. Nature Geoscience 7, 909-913. doi:10.1038/ngeo2291

Syracuse, E.M., van Keken, P.E., Abers, G.A., 2010. The global range of subduction zone thermal models. Physics of the Earth and Planetary Interiors 183, 73-90. doi:10.1016/j.pepi.2010.02.004

Valley, J.W., 1986. Stable isotope geochemistry of metamorphic rocks. Reviews in Mineralogy and Geochemistry 16, 445-489.

Vitale Brovarone, A., Alard, O., Beyssac, O., Martin, L., Picatto, M., 2014. Lawsonite metasomatism and trace element recycling in subduction zones. Journal of Metamorphic Geology 32, 489-514. doi:10.1111/jmg.12074

Vitale Brovarone, A., Beltrando, M., Malavieille, J., Giuntoli, F., Tondella, E., Groppo, C., Beyssac, O., Compagnoni, R., 2011b. Inherited Ocean-Continent Transition zones in deeply subducted terranes: Insights from Alpine Corsica. Lithos 124, 273-290. doi:10.1016/j.lithos.2011.02.013

Vitale Brovarone, A., Beyssac, O., 2014. Lawsonite metasomatism: A new route for water to the deep Earth. Earth and Planetary Science Letters 393, 275-284. doi:10.1016/j.eps1.2014.03.001

Vitale Brovarone, A., Beyssac, O., Malavieille, J., Molli, G., Beltrando, M., Compagnoni, R., 2013. Stacking and metamorphism of continuous segments of subducted lithosphere in a high-pressure wedge: The example of Alpine Corsica (France). Earth-Science Reviews 116, 35-56. doi:10.1016/j.earscirev.2012.10.003

Vitale Brovarone, A., Groppo, C., HetéNyi, G., Compagnoni, R., Malavieille, J., 2011a. Coexistence of lawsonite-bearing eclogite and blueschist: phase equilibria modelling of Alpine Corsica metabasalts and petrological evolution of subducting slabs. Journal of Metamorphic Geology 29, 583-600. doi:10.1111/j.1525-1314.2011.00931.x

Vitale Brovarone, A., Herwartz, D., 2013. Timing of HP metamorphism in the Schistes Lustrés of Alpine Corsica: New Lu-Hf garnet and lawsonite ages. Lithos 172-173, 175-191. doi:10.1016/j.lithos.2013.03.009 
827 Wang, Q., Rumble, D., 1999. Oxygen and carbon isotope composition from the UHP Shuanghe marbles, Dabie 828 Mountains, China. Science in China Series D: Earth Sciences 42, 88-96.

Wilson, C.R., Spiegelman, M., van Keken, P.E., Hacker, B.R., 2014. Fluid flow in subduction zones: The role of solid rheology and compaction pressure. Earth and Planetary Science Letters 401, 261-274. doi:10.1016/j.eps1.2014.05.052 
833 Fig.1: Geological background of the study area. a) Simplified regional setting of Alpine Corsica (France) in the 834 Western Mediterranean region. Modified after Molli and Malavieille (2011). b) Simplified tectono-stratigraphic 835 map of Alpine Corsica. The black box indicates the position of the study area. c) Simplified geological map of 836 the San Petrone unit. Figures modified after Vitale Brovarone et al. (2013).

Fig. 2: simplified structural sketch summarizing the field relationships between the different rock types and the location of the study samples. The star refers to metasomatic marbles formed at the expense of former serpentinites.

Fig. 3: Representative textural features of metasomatic marble in the field. a) Crack-seal texture in a metasomatic marble lens located in the metasomatic rind formed along the continental basement-serpentinite contact. Dashed lines mark the schistosity in the host rock and the orientation of the remains of the host rock in the carbonate-rich domain (see detail in b). Note that the silicate layers are deflected toward the carbonate vein. b) Detail of carbonate layers containing rod-shaped aragonite pseudomorphs alternating with vein-parallel bands of wallrock inclusions. c) Interdigitation of rod-shape carbonate with Stage\#1 diopside-lawsonite rock. d)

848 Carbonate+omphacite vein cutting across Stage\#1 diopside+lawsonite rock. The black dotted line marks the vein wall and the green area overdrawn marks the selvage extension. e) and f) Photograph and related interpretative sketch of a hydraulic breccia (types defined by Jébrak 1997) consisting of angular clasts of diopside+lawsonite rock (Stage\#1 metasomatism) sealed by a network of veins containing rod-shaped carbonate crystals. $g$ and $h$ ) Outcrop with high carbonate/silicate ratio and corresponding sketch. Rounded chunks of Stage\#1 diopsidelawsonite rock float in a carbonate matrix. Microtextures in the carbonate-rich domains suggest digestion and chemical replacement of Stage\#1 silicates by carbonate. Di=diospide; Lws=lawsonite.

856 Fig. 4: Progressive transformation of a precursor Stage\#1 carbonate-free, diopside-lawsonite rock into a Stage\#2 857 metasomatic marble. a) Stage\#2 metasomatic marble cropping out along the serpentinite-metasediment contact. 858 The marble (grey) is interdigitated with the host Stage\#1 diopside-lawsonite rock (green). The foliation of the 859 diopsode-lawsonite rock (dashed line) can be followed in the carbonate layer. b) Thin section scan showing the 860 interdigitation texture of silicate and carbonate layers analogous to that documented at the outcrop scale in part 861 (a). Different degrees of carbonation are observed. White boxes indicate the location of the photomicrographs c, $862 \mathrm{~d}$ and e. c) Plane polarized light photomicrograph and corresponding sketch of the preserved portion of the metasomatic diopside + lawsonite protolith; fan-shape diopside and lawsonite crystals statically crystallized. d)

864 Plane polarized light photomicrograph and corresponding sketch of the patchy distribution of carbonate pods that characterizes a partially carbonated domain. Here, Stage\#1 diopside aggregates are cut by the carbonate and some fragments are preserved as relicts in carbonate layers. e) Plane polarized light photomicrograph and corresponding sketch of a highly carbonated portion. Here the rock is transformed into a metasomatic marble; prismatic carbonate crystals are well developed. A few remnants of Stage\#1 diopside are preserved; these relicts

869 display embayed rims and atoll-like textures. In every sketch, Stage\#1 diopside + lawsonite domains are represented in green, whereas rod-shaped carbonate is in light beige. 
Fig. 5: Backscattered electron (BSE) images obtained by SEM depicting micro scale textural relationships resulting from fluid-rock interaction. a) BSE image of atoll-like Stage\#1 diopside suggesting a digestion of a silicate clast by carbonate; the Stage\#1 diopsidic core is dissolved in favor of carbonate while a Stage\#2 Na-Al rich rim (omphacite) crystallized in textural equilibrium with the carbonate. Small fragments of diopside are preserved as inclusions in carbonate crystals (red lines). b) BSE image of wallrock selvage shown in Figure $3 \mathrm{~d}$. Diopside is overgrown by omphacite rim. Omphacite rims have the same composition as the vein infill omphacite crystals (Table S1). c) Plane polarized light photomicrograph of diopside with aegirine-augite rim in sample COR13-21d. $\mathrm{Cal}=$ calcite, $\mathrm{Omp}=$ omphacite, $\mathrm{Di}=$ diopside; $\mathrm{Agt}=$ aegirine-augite, Act=actinolite.

Fig. 6: Whole-rock chondrite normalized REE patterns (CI values from Sun and McDonough, 1989) for metasomatic marbles (orange lines, see Fig. S3 for details), reference calcschist and ophicarbonate (solid and dashed black lines, respectively), and Stage\#1 diopside + lawsonite metasomatic rock (solid green line). The shaded field represents the range of passive margin serpentinite whole-rock compositions (either actual or metamorphic equivalent of Tethyan ocean floor; data from Barnes et al., 2014; Kodolányi et al., 2012).

Fig. 7: Carbon and Oxygen stable isotopic analyses of calcite. a) Calcite $\delta^{13} \mathrm{C}$ vs. $\delta^{18} \mathrm{O}$ plot of metasomatic marbles (this study), blueschist and eclogite-facies marbles and calcite veins from other studies (Ague and Nicolescu, 2014; Cartwright and Buick, 2000; Cook-Kollars et al., 2014; Galvez et al., 2013b). Only data for non-metasomatic calcschists in Ague and Nicolescu (2014) and Galvez et al. (2013b) are reported. b) The rock silicate mineral content vs. calcite $\delta^{18} \mathrm{O}$ values. The dispersion of data illustrates the lack of correlation between the light $\mathrm{O}$ isotopic signature and the silicate content. Analyses of reference calcschists and ophicarbonate are also reported. We plotted data for samples that were also analyzed for their bulk rock composition (samples COR13-32; COR13-30a; COR13-21b; COR13-21d; COR13-27e; COR13-17c; COR13-22c; COR13-28c; Table S3). c) Metasomatic marble and reference calcschists $\delta^{18} \mathrm{O}$ vs. $\delta^{13} \mathrm{C}$ plot. Shaded areas correspond to geochemical trend of carbonate affected by devolatilization (Bowman et al., 2009; Gerdes et al., 1995, 1999), and carbonate reduction (Galvez et al., 2013b). Isotopic composition of carbonates affected by carbonate dissolution is also reported (blue diamonds, Ague and Nicolescu, 2014).

Fig. 8: Carbon fluxes during subduction metamorphism. a) Bar diagram reporting the estimation of grams of $\mathrm{CO}_{2}$ release per $100 \mathrm{~g}$ of precursor rock during carbonate dissolution (Ague and Nicolescu 2014, blue bar) and decarbonation reactions (Cook-Kollars et al., 2014, calculation by Perple_X software and natural sample estimation, green and orange bars respectively) and grams of $\mathrm{CO}_{2}$ bound per $100 \mathrm{~g}$ of precursor rock via carbonate precipitation (red bar, this study). b) Contours of $[\mathrm{C}]$ in parts per million for aqueous fluid saturated in $\mathrm{CaCO}_{3}$ as a function of $\mathrm{P}$ and $\mathrm{T}$. The red arrow indicates the P-T path of Alpine Corsica (Vitale Brovarone et al., 2011a). The star corresponds to the $\Delta_{\text {cal-omp }}$ equilibrium temperature. The green field represents the predicted P-T

907 path for active subduction (D80 model, Syracuse et al., 2010). Figure adapted from Kelemen \& Manning (2015).

909 Fig. 9: Schematic illustration showing the percolation of $\mathrm{COH}$ fluids parallel to the subducting slab. The 
911 with slab or mantle rock is a suitable context for carbonate precipitation via vein injection and mineral

912 carbonation.

913

914 Table 1: Whole rock major element composition of metasomatic marble, Stage\#1 diopside+lawsonite rock

915 (OF3598) and Stage\#1 rock with lawsonite $>70 \%$ (COE5)

916

917 Fig. S1: Raman spectrum of aragonite inclusion in garnet.

918 Fig. S2: picture showing a detail of an omphacite-calcite vein. Omphacite grows from the vein wall toward the 919 center.

920 Fig. S3: Whole-rock chondrite normalized REE patterns (CI values from Sun and McDonough, 1989) for 921 metasomatic marbles, reference calcschist and ophicarbonate (solid and dashed black lines, respectively), and 922 Stage\#1 diopside + lawsonite metasomatic rock (dashed blue line). The shaded field represents the range of 923 passive margin serpentinite whole-rock compositions (either actual or metamorphic equivalent of Tethyan ocean 924 floor; data from Barnes et al., 2014; Kodolányi et al., 2012).

925 Table S1: Representative clinopyroxene analyses.

926 Table S2: Whole rock composition of analyzed samples (major and selected trace elements). Analyses below 927 the lower detection limit are labeled "<d.1.". Values in wt.\%.

928 Table S3: Stable isotopes analyses of calcite. Analyses made in duplicate.

929 Table S3.1: Stable oxygen isotopes analyses of clinopyroxenes, average value of calcite filling vein and 930 calculated equilibrium $\mathrm{T}$.

931 Table S4: Representative garnet analyses.

932 Table S5: Representative amphibole, lawsonite, phengite, pumpellyite analyses. 
(a)
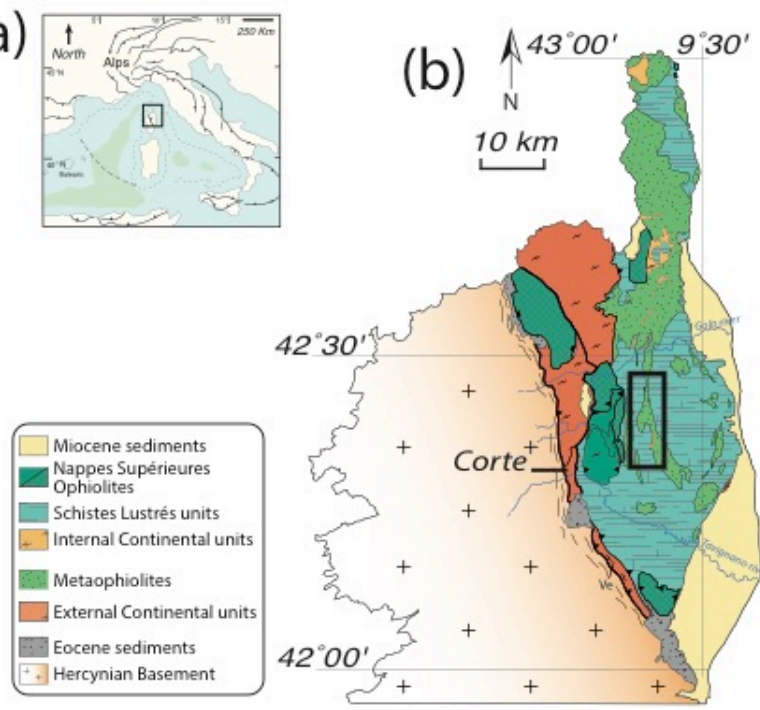

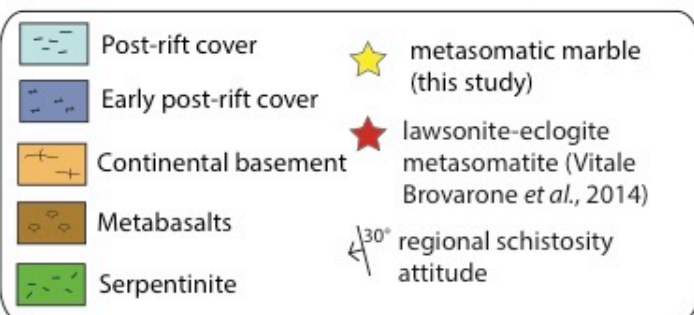

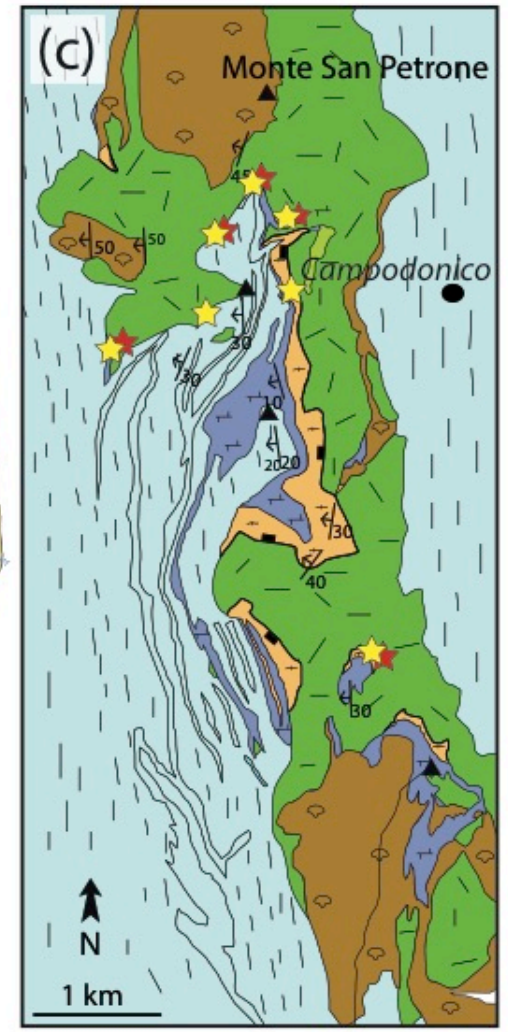

\section{$934 \quad$ Fig. 1}

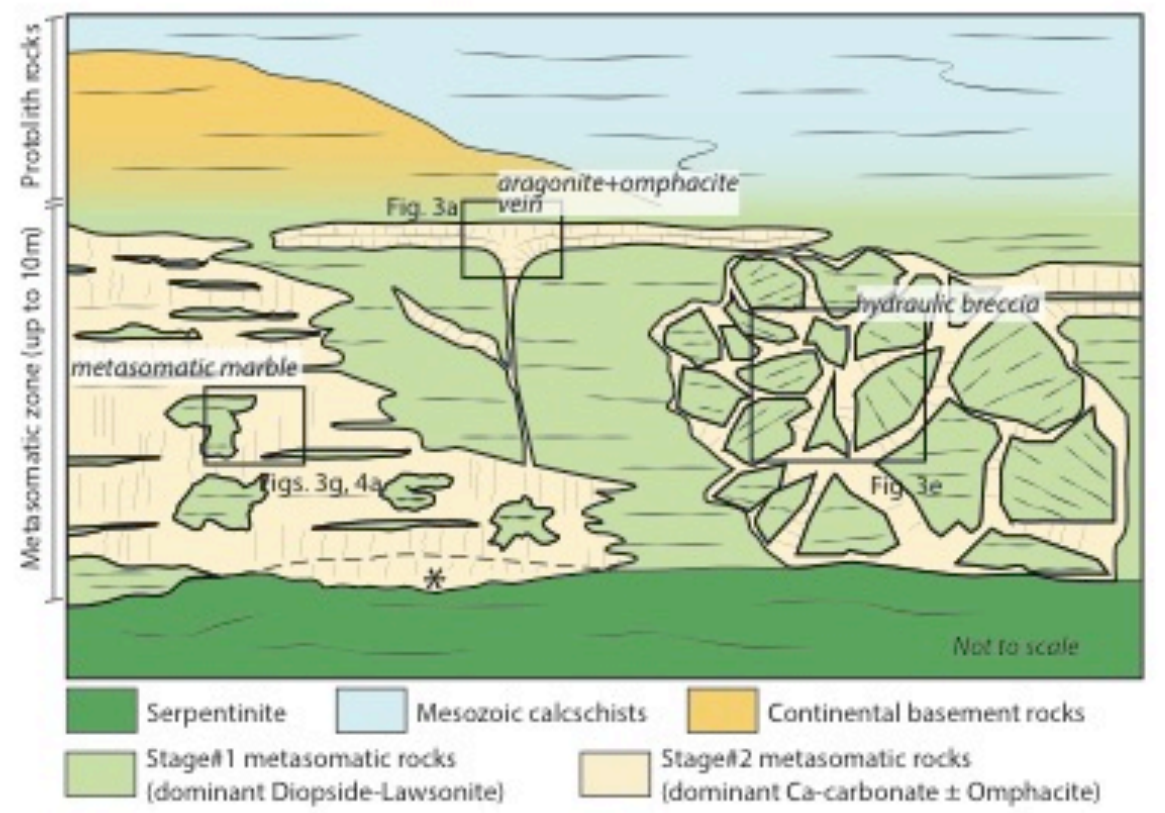

Fig. 2 

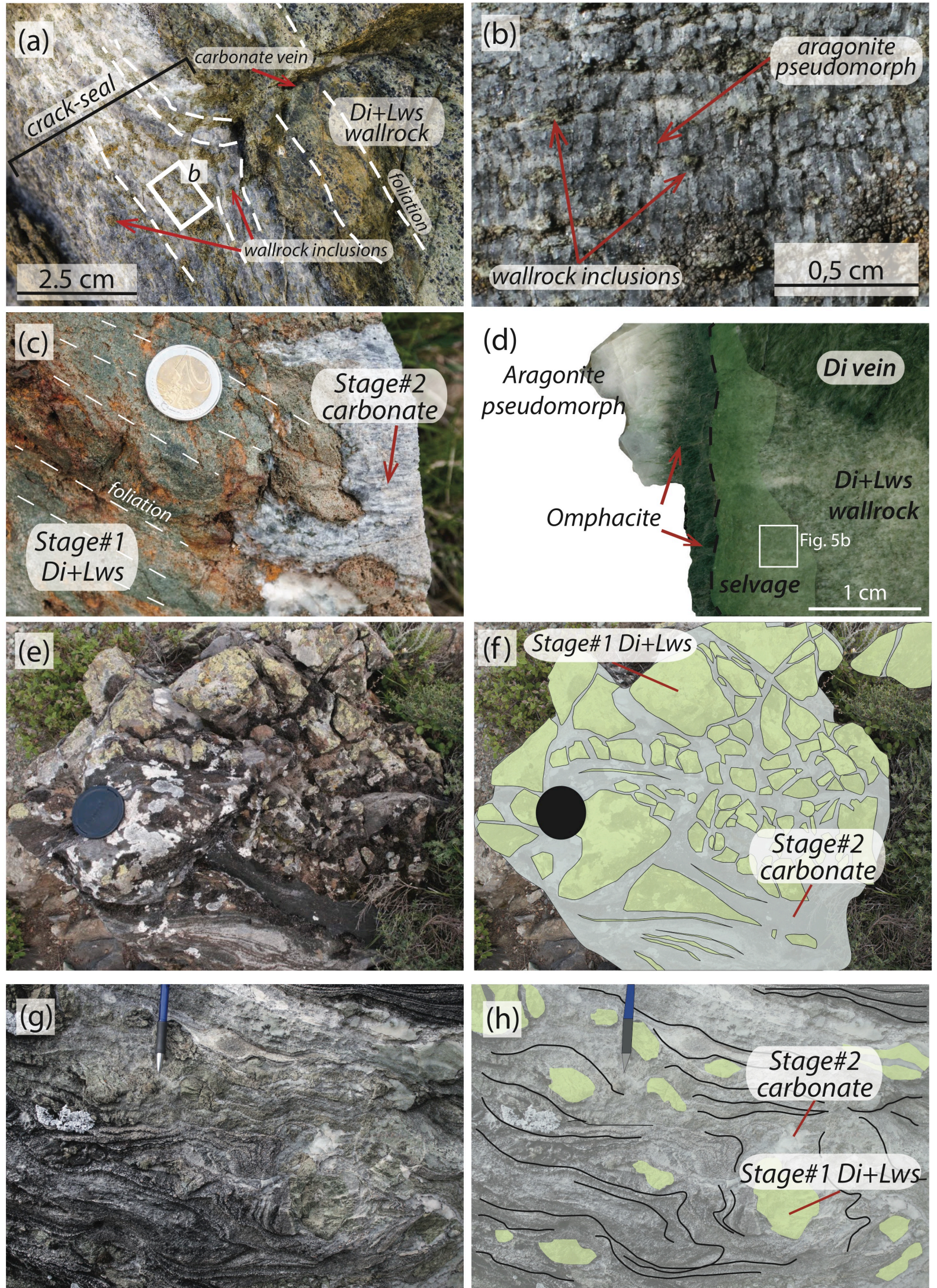

Fig. 3 

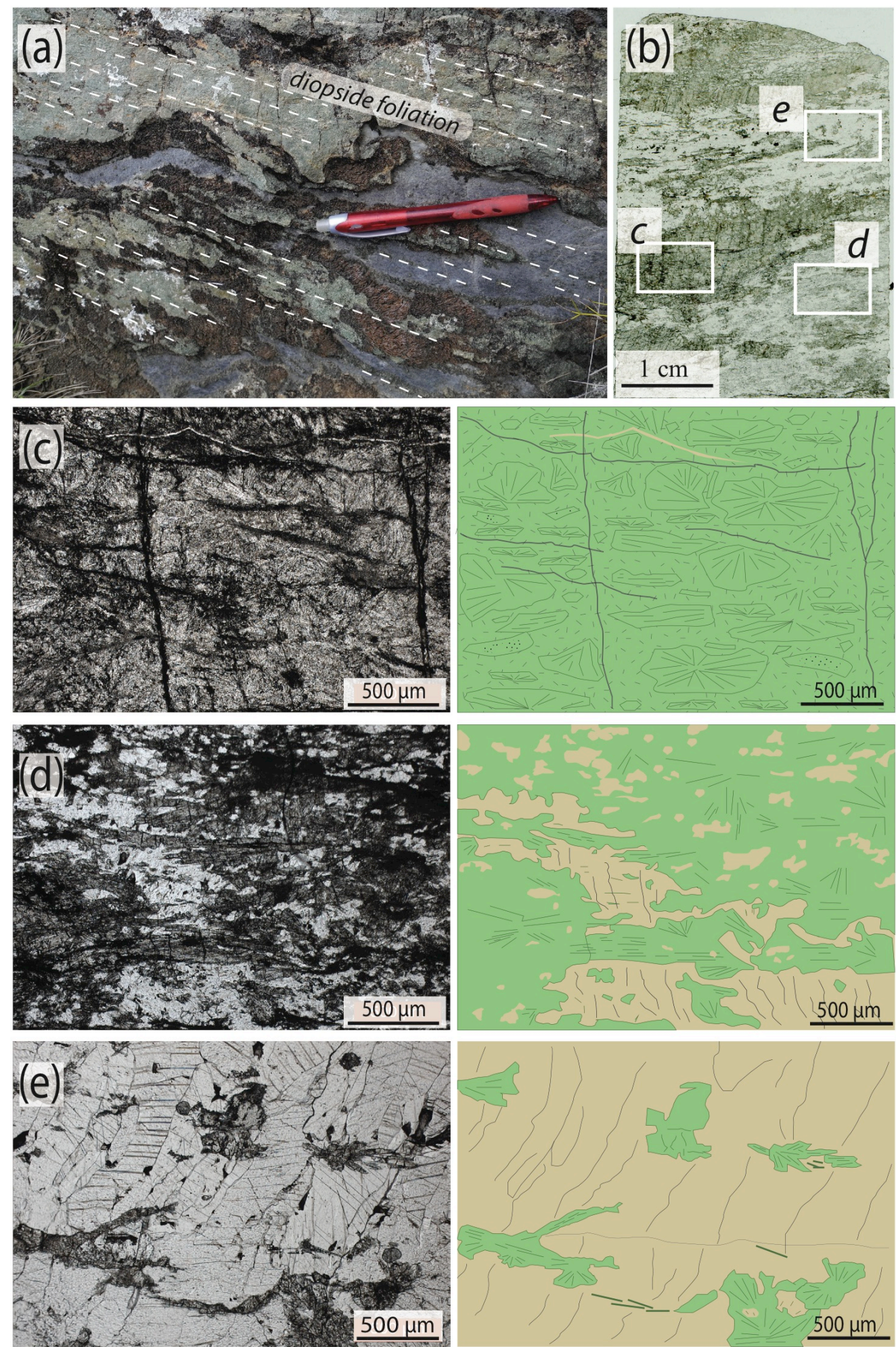

Fig. 4 

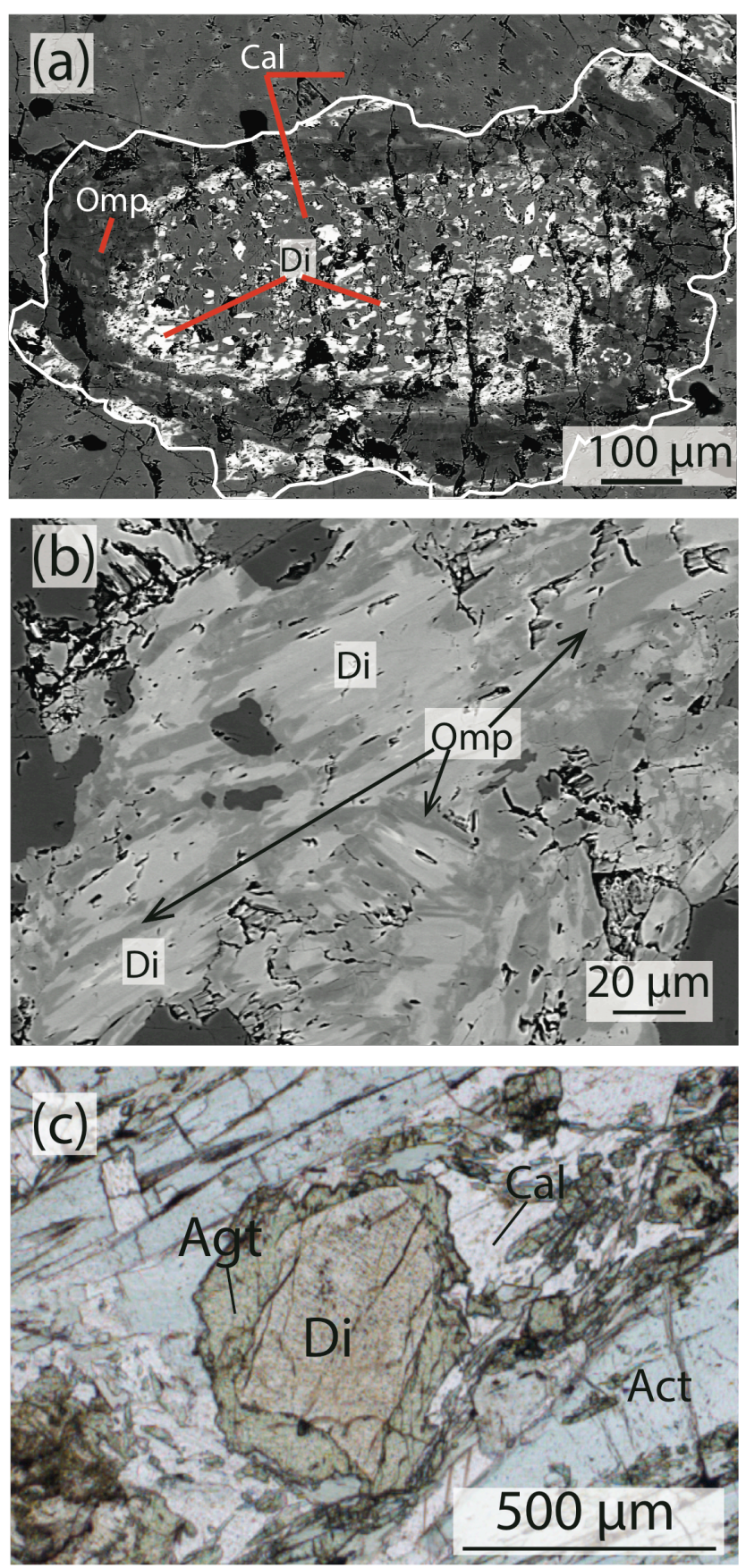

\section{$943 \quad$ Fig. 5}




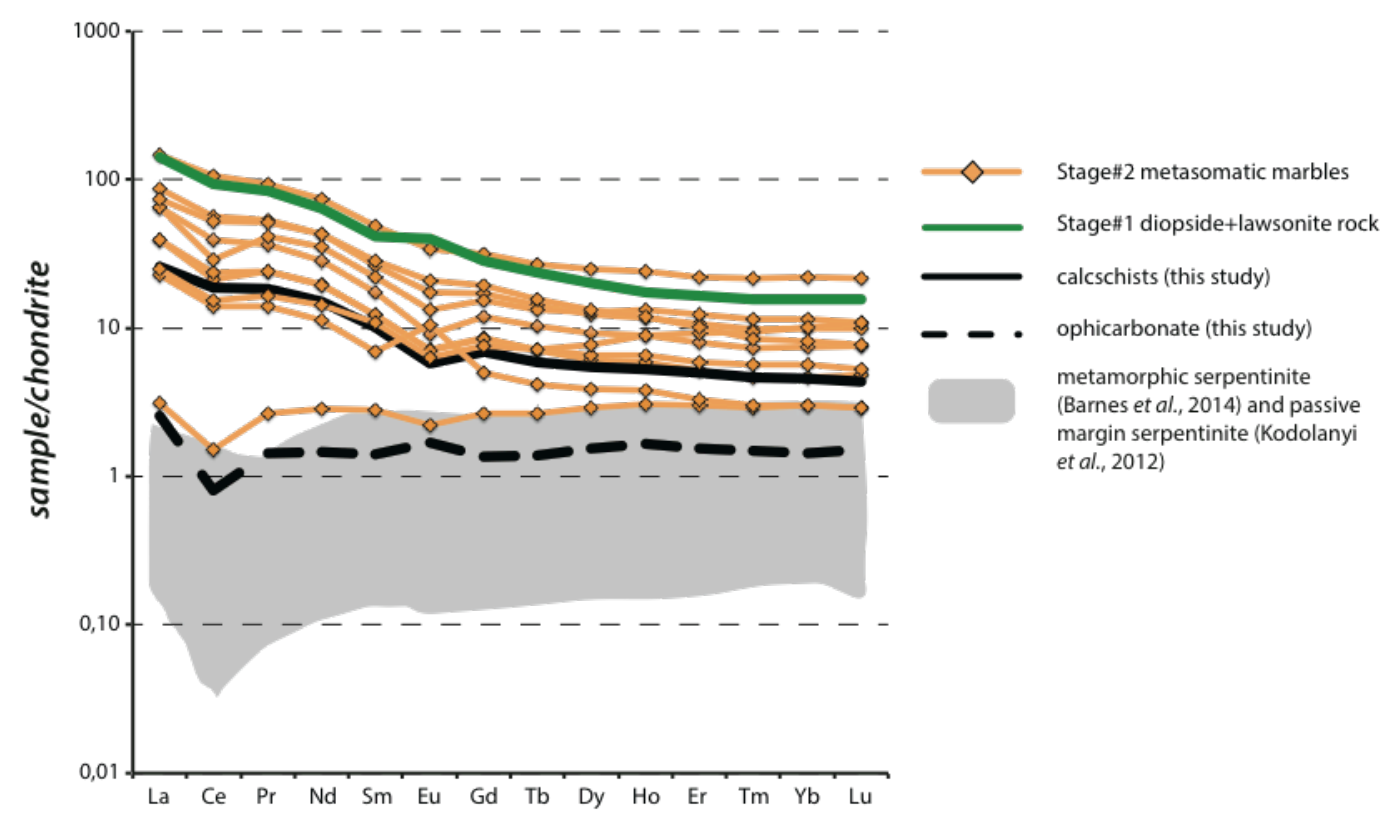

945 Fig. 6

$\begin{array}{llll}\text { (a) } \delta^{13} C^{6} & { }^{6}\end{array}$

(b) $\delta^{18} \mathrm{O}^{25}$

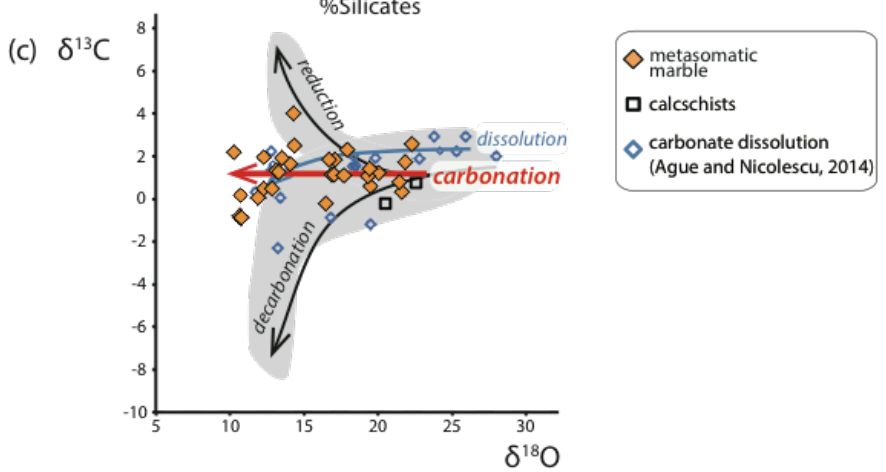

\section{$946 \quad$ Fig. 7}


(a)

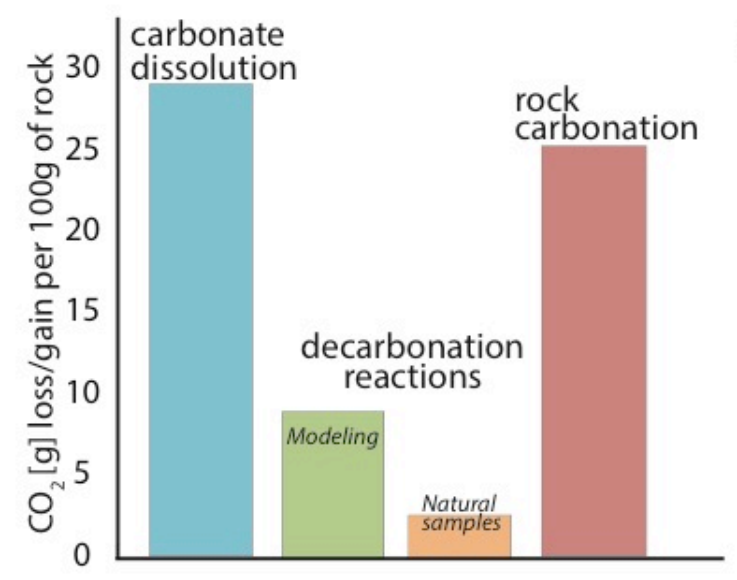

(b)

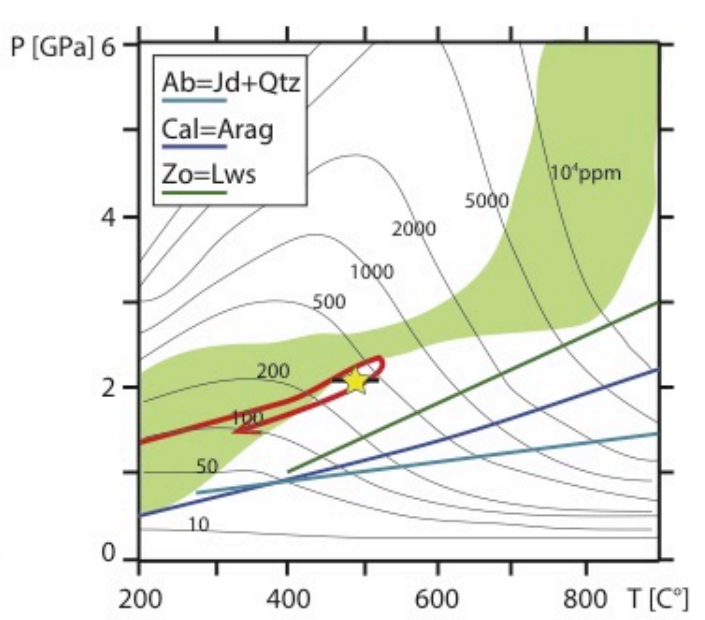

\section{$948 \quad$ Fig. 8}

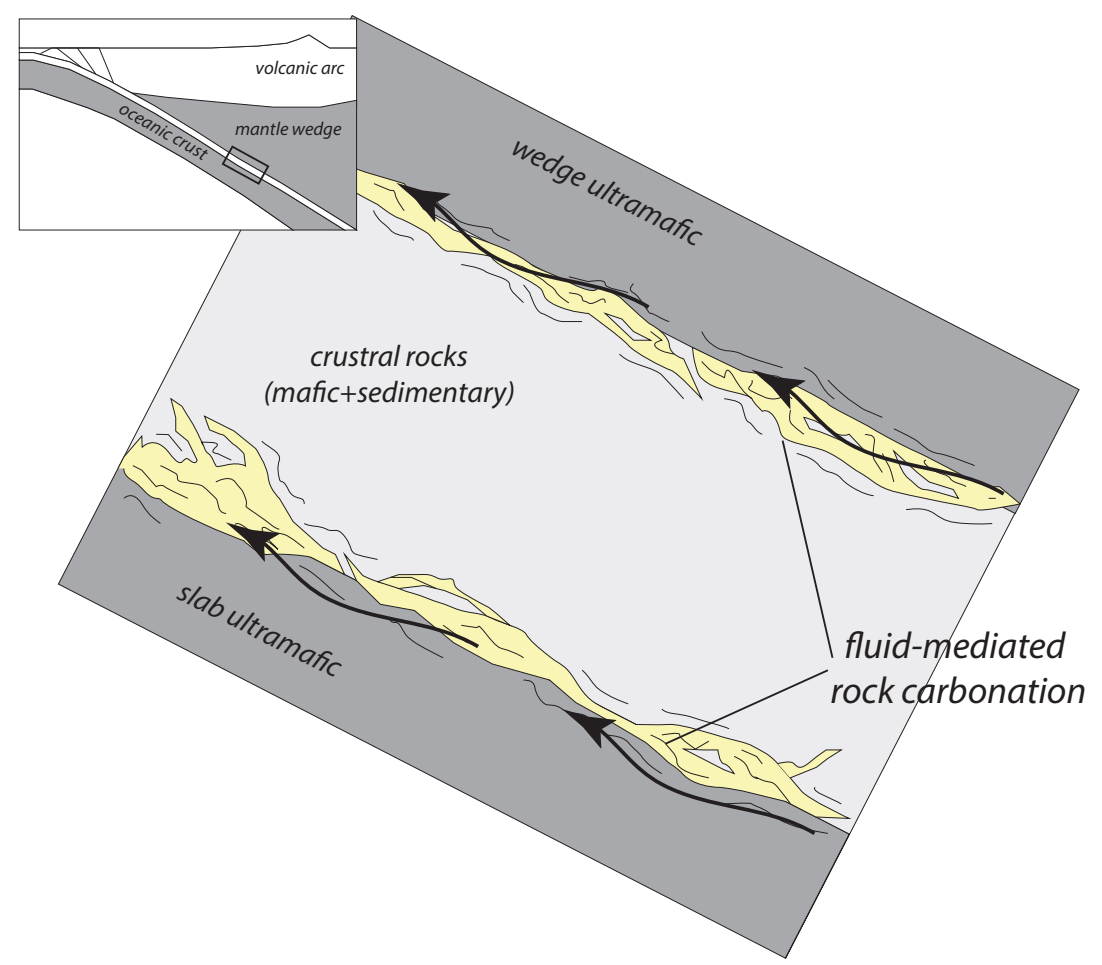

\section{$949 \quad$ Fig. 9}


Table 1: whole rock major element composition for metasomatic marbles (see Table S2 for details), Stage\#1 diopside-lawsonite rock (OF3598) and Stage\#1 rock with lawsonite $>70 \%$ (COE5).

\begin{tabular}{|c|c|c|c|c|}
\hline \multirow[b]{2}{*}{ Sample } & \multirow{2}{*}{$\begin{array}{l}\text { Metasomatic } \\
\text { marble }(n=4)\end{array}$} & \multirow{2}{*}{$1 \sigma$} & OF3598 $^{\mathrm{a}}$ & $\mathrm{COE5}^{\mathrm{b}}$ \\
\hline & & & \multicolumn{2}{|c|}{ Stage\#1 rock } \\
\hline $\mathrm{SiO} 2$ & 20.44 & 5.65 & 45.30 & 40.6 \\
\hline Al2O3 & 4.97 & 2.94 & 15.11 & 25.6 \\
\hline Fe2O3 & 3.22 & 1.14 & 5.03 & 2.28 \\
\hline MnO & 0.18 & 0.16 & 0.11 & 0.13 \\
\hline MgO & 3.14 & 1.77 & 6.95 & 1.8 \\
\hline $\mathrm{CaO}$ & 39.23 & 5.32 & 20.62 & 17.65 \\
\hline $\mathrm{Na} 2 \mathrm{O}$ & 0.92 & 0.95 & 0.47 & 0.51 \\
\hline K2O & 0.12 & 0.16 & 0.01 & 0.24 \\
\hline $\mathrm{TiO} 2$ & 0.18 & 0.11 & 0.65 & 1.94 \\
\hline P2O5 & 0.09 & 0.04 & 0.11 & 0.41 \\
\hline LOI & 27.05 & 5.12 & 5.57 & 7.94 \\
\hline Tot & 99.54 & & 99.94 & 99.10 \\
\hline
\end{tabular}

950 